\title{
Foundation species loss affects vegetation structure more than ecosystem function in a northeastern USA forest
}

Loss of foundation tree species rapidly alters ecological processes in forested ecosystems. Tsuga canadensis, an hypothesized foundation species of eastern North American forests, is declining throughout much of its range due to infestation by the nonnative insect Adelges tsugae and by removal through pre-emptive salvage logging. In replicate 0.81-ha plots, $T$. canadensis was cut and removed, or killed in place by girdling to simulate adelgid damage. Control plots included undisturbed hemlock and mid-successional hardwood stands that represent expected forest composition in 50-100 years. Vegetation richness, understory vegetation cover, soil carbon flux, and nitrogen cycling were measured for two years prior to, and five years following, application of experimental treatments. Litterfall and coarse woody debris (CWD), including snags, stumps, and fallen logs and branches, have been measured since treatments were applied. Overstory basal area was reduced 60-70\% in girdled and logged plots. Mean cover and richness did not change in hardwood or hemlock control plots but increased rapidly in girdled and logged plots. Following logging, litterfall immediately decreased then slowly increased, whereas in girdled plots, there was a short pulse of hemlock litterfall as trees died. CWD volume remained relatively constant throughout but was 3-4× higher in logged plots. Logging and girdling resulted in small, short-term changes in ecosystem dynamics due to rapid regrowth of vegetation but in general, interannual variability exceeded differences among treatments. Soil carbon flux in girdled plots showed the strongest response: 35\% lower than controls after three years and slowly increasing thereafter. Ammonium availability increased immediately after logging and two years after girdling, due to increased light and soil temperatures and nutrient pulses from leaf-fall and reduced uptake following tree death. The results from this study illuminate ecological processes underlying patterns observed consistently in region-wide studies of adelgid-infested hemlock stands. Mechanisms of $T$. canadensis loss determine rates, magnitudes, and trajectories of ecological changes in hemlock forests. Logging causes abrupt, large changes in vegetation structure whereas girdling (and by inference, $A$. tsugae) causes sustained, smaller changes. Ecosystem processes depend more on vegetation cover per se than on species composition. We conclude that the loss of this 
late-successional foundation species will have long-lasting impacts on forest structure but subtle impacts on ecosystem function. 
1 David A. Orwig, ${ }^{1}$ Audrey A. Barker Plotkin, ${ }^{1}$ Eric A. Davidson, ${ }^{2}$ Heidi Lux,${ }^{1}$ Kathleen E.

2 Savage ${ }^{2}$ and Aaron M. Ellison ${ }^{1 *}$

3

$4 \quad{ }^{1}$ Harvard University, Harvard Forest, 324 North Main Street, Petersham, Massachusetts

501366 USA

$6{ }^{2}$ Woods Hole Research Center, 149 Woods Hole Road, Falmouth, Massachusetts

$7 \quad 02540$ USA

8

9 *Author for correspondence: Aaron M. Ellison, Harvard University, Harvard Forest, 324

10 North Main Street, Petersham, Massachusetts 01366 USA; aellison@fas.harvard.edu;

11 tel: +1-978-756-6178 


\section{Introduction}

Changes in the distribution and abundance of canopy trees have system-wide impacts on ecological processes in forests (Lovett et al. 2006; Wardle et al. 2011; Hicke et al. 2012). Changes in species composition and the associated ecological impacts also lead to changes in the values - including economic, utilitarian, and aesthetic - that we place on forest ecosystems (e.g., Aukema et al. 2011; Cardinale et al. 2012). The vast majority of studies of the impacts of species loss on ecological processes in forests and other ecosystems have examined how changes in the absolute number (or percent) of species lost affects a wide range of ecosystem services (recently reviewed by Wardle et al. 2011; Cardinale et al. 2012; Hooper et al. 2012; Naeem et al. 2012). However, species are not lost from ecosystems at random (e.g., Bunker et al. 2005) and it remains an open question whether particular species with particular characteristics will disproportionately change how ecosystems function (Bunker et al. 2005; Suding et al. 2008; B. Baiser \& A. M. Ellison unpublished data). Foundation species (sensu Ellison et al. 2005a) define and structure many terrestrial, aquatic, and marine ecosystems, yet because foundation species often are abundant and widespread, their role in structuring ecosystems is often underappreciated or taken for granted and they are rarely of explicit conservation interest (Gaston 2010). Ellison et al. (2005a) suggested that the loss of foundation species can cause strong, widespread, and long-lasting changes to forest ecosystems because forest-wide biological diversity and ecosystem processes such as primary productivity and fluxes of energy and nutrients are hypothesized to depend more on foundation species than on any other species in the system. Examples where loss of 
dominant, and possibly foundational, tree species have had large impacts on forest ecology include: regional loss of associated fauna as white pines (Pinus subgenus strobus) in western North America succumb to white pine blister rust (Cronartium ribicola A. Dietr.); changes in canopy structure as a result of fire suppression, mountain pine beetle irruptions (Dendroctonus ponderosae Hopkins), and climatic change (Kendall \& Deane 2001; Tomback \& Achuff 2010); shifts in understory composition, recruitment, and regeneration dynamics following loss of American beech (Fagus grandifolia Ehrh.), American chestnut (Castanea dentata (Marsh.) Borkh.) or American elm (Ulmus americana L.) due to beech-bark disease (Nectria coccinea (Pers. ex. Fr.) Fries var. faginata Lohman, Watson and Ayers), chestnut blight (Cryphonectria parasitica (Murrill) Barr.) and Dutch elm disease (Ceratocystis ulmi (Buism.) C. Moreau), respectively (McBride 1973; Houston 1975; Barnes 1976; Huenneke 1983; Twery \& Patterson 1984; Myers, Walck \& Blum 2004; Lovett et al. 2006); changes in faunal (Wills 1993) and macrofungal diversity (Anderson et al. 2010) and functional diversity of soil bacteria involved in carbon and nitrogen cycling (Cai et al. 2010) following loss of Eucalyptus to Phytophthora outbreaks in Australia; bottom-up control by Populus spp. of associated herbivorous arthropod populations, which in turn mediates how insectivorous birds influence future tree growth in the southwestern United States (Bridgeland et al. 2010); and the dependence of benthic biological diversity, productivity, and nutrient cycling on a handful of species in mangrove forests (e.g., Nagelkerken et al. 2008; Barbier et al. 2011).

Tsuga canadensis (L.) Carr. (eastern hemlock) has been hypothesized to be a foundation tree species (Ellison et al. 2005a) that covers $\approx 10000 \mathrm{~km}^{2}$ and comprises $\approx 2$ 
$58 \times 10^{8} \mathrm{~m}^{3}$ of harvestable and merchantable volume from the southern Appalachian

Mountains north into southern Canada and west across the upper Midwestern states in North America (Fig. 1; Smith et al. 2009). Like other putative foundation tree species, $T$. canadensis can account locally for $>50 \%$ of the total basal area and its ecological traits create unique terrestrial and aquatic habitats. For example, the deep shade cast by its dense evergreen foliage limits establishment of most understory species (Rogers 1980; D'Amato, Orwig \& Foster 2009). Its refractory leaf litter and the cool temperatures at the soil surface beneath dark hemlock canopies result in low rates of decomposition and nutrient cycling, rapid accumulation of organic matter (Aber \& Melillo 1991; Jenkins, Aber \& Canham 1999), and nutrient-poor soils. The combination of nearly year-round low photosynthetic and evapotranspiration rates of $T$. canadensis stabilizes stream base-flows and decreases daily variation in stream temperatures (Ford \& Vose 2007; Hadley et al. 2008; Nuckolls et al. 2009). The microhabitat created by eastern hemlock supports unique assemblages of birds, arthropods, salamanders, and fish (Snyder et al. 2002; Tingley et al. 2002; Ellison et al. 2005b; Dilling et al. 2007; Mathewson 2009; Rohr, Mahan \& Kim 2009; Mallis \& Rieske, 2011; Sackett et al. 2011). Despite its widespread distribution and high abundance, both locally and regionally, $T$. canadensis is rapidly disappearing across an increasing extent of its range. The hemlock woolly adelgid (Adelges tsugae Annand), an invasive insect from Japan that in North America feeds exclusively on eastern hemlock and its southeastern (USA) endemic congener, Carolina hemlock ( $T$. caroliniana Engelmann), is moving rapidly both southward and northward (Fitzpatrick et al. 2012), killing $>90 \%$ of hemlocks it encounters (Orwig et al. 2002; Eschtruth et al. 2006; Knoepp et al. 2011). Hemlock 
81 has little resistance to the adelgid (Ingwell \& Preisser 2011) and as yet has shown no 82 recovery from chronic infestations (McClure 1995; Orwig et al. 2012). In the absence of

83

successful biological control programs (Onken \& Reardon 2011) and economically or logistically feasible chemical control options (Ward et al. 2004; Cowles 2009), pre-emptive cutting or salvage logging of hemlock has been a common management response to declining and dead hemlock stands affected by the adelgid (Kizlinski et al. 2002; Orwig et al. 2002; Ward et al. 2004; Foster \& Orwig 2006).

The combination of adelgid-induced morbidity and mortality and pre-emptive salvage logging of $T$. canadensis is radically changing the structure of eastern USA forests. Region-wide, forest productivity and carbon sequestration are expected to decline by as much as 8-12\%, but establishment of mid-successional hardwoods (e.g., Betula and Acer species) is forecast to result in forest carbon uptake recovering to, or even exceeding pre-adelgid conditions only after 50 years or more (Albani et al. 2010; Knoepp et al. 2011; Fitzpatrick et al. 2012). These model forecasts of the impact of the adelgid have been made at coarse-grained scales ( $2.5^{\circ}$ grid), but local impacts may fall short of or dramatically exceed regional averages (P. C. Lemos \& A. C. Finzi, unpublished data). Fifteen years of observational studies of marked plots have illustrated high variance in forest dynamics (e.g., Orwig, Foster \& Mausel 2002; Orwig et al. 2008, 2012), portions of which may be attributable to differences in climate, shortversus long-term impacts of logging and/or fine-scale effects of the adelgid itself (Stadler et al. 2005; Stadler, Müller \& Orwig 2006).

Only experimental studies can distinguish reliably among differences due to in situ forest disintegration or logging, and so in 2003 we established a multi-hectare, 
104 long-term manipulative study - the Harvard Forest Hemlock Removal Experiment 105 (HF-HeRE; Ellison et al. 2010) - to study the various forest responses to the loss of

106

107

108

109

110

111

112

113

114

115

116

117

118

119

120

121

122

123

124

125

hemlock. This ongoing experiment compares and contrasts the rates, magnitudes, and trajectories of changes in hemlock-dominated stands to two mechanisms of foundation species loss: (1) death in place of eastern hemlock by girdling, which mimics tree disintegration that follows infestation by the hemlock woolly adelgid (Yorks et al. 2003); or (2) loss and removal of hemlock following commercial logging (Brooks 2001).

Patterns, processes and dynamics studied include: forest vegetation structure, standing and downed dead wood, and three measures of ecosystem function: litterfall (a substantial component of net primary productivity; e.g., Zheng et al. 2004), soil carbon flux, and soil nitrogen dynamics.

In this paper, we report two years of pre-treatment data and the first five years of changes in vegetation structure and ecosystem functions following our experimental manipulations but prior to the infestation of our experimental plots by the adelgid. In particular, we examine and test three predictions that, relative to both hemlock and hardwood controls:

(1) Vegetation structure - species richness and cover of understory herbs, and density and cover of tree seedlings and saplings - increases slowly following girdling but more rapidly following hemlock removal and soil scarification from logging;

(2) Standing volume of standing dead wood and snags is highest in girdled plots, but downed coarse woody debris is higher in logged plots; 
(3) Core ecosystem functions - litterfall and soil carbon fluxes decline while rates of soil nitrogen (as nitrate and ammonium) mineralization and soil nitrogen availability increase then decline slowly in girdled plots but rapidly in logged plots Other papers have described changes in the microenvironment (Lustenhouwer, Nicoll \& Ellison 2012), species composition of the seed bank and understory vegetation (Farnsworth, Barker Plotkin \& Ellison 2012), diversity of ground-dwelling arthropods (Sackett et al. 2011), and nitrogen leaching (Templer \& McCann 2010) in the first decade following the canopy manipulations in HF-HeRE. In total, our results lead us to hypothesize that vegetation structure and ecosystem functions in the girdled and logged plots will converge through time, and, at least on decadal scales, come to resemble the attributes of the hardwood control plots.

We note that we purposely sited HF-HeRE north of the northern limit (in 2003) of the hemlock woolly adelgid so that we could first identify different effects on forest structure and function caused by two different kinds of physical loss of $T$. canadensis. This experiment complements a suite of studies in which we have examined landscape-level spread of the adelgid (Orwig, Foster \& Mausel 2002; Fitzpatrick et al. 2012; Orwig et al. 2012), compositional and structural changes in forest vegetation (Foster \& Orwig 1998), and ecosystem functions in forests infested by the adelgid (Cobb, Orwig \& Currie 2006; Orwig et al. 2008) or that have been salvage logged (Kizlinski et al. 2002, D. A. Orwig et al. unpublished data). Subsequent data collected after the adelgid colonizes HF-HeRE (which occurred in 2010), will be used to further distinguish effects on eastern North American forests of physical disintegration of $T$. canadensis from additive, interactive, and/or nonlinear effects of the insect itself (e.g., 
149 Stadler et al. 2005; Stadler, Müller \& Orwig 2006). The unique experimental design -

150

151

152

153 154 itself.

155

156

157

158

159

160

161

162

163

164

165

166

167

168

169

170

171

with measurements made pre-treatment; post-treatment but pre-adelgid; and

post-treatment, post-adelgid - distinguishes HF-HeRE from other studies, both

observational and experimental, that have examined the effects of foundation species

loss but that cannot separate effects of physical loss from those of the agent of loss

\section{Materials and Methods}

\section{Site Description}

HF-HeRE is located within the 121 -ha Simes Tract $\left(42.47^{\circ}-42.48^{\circ} \mathrm{N}, 72.22^{\circ}-72.21^{\circ}\right.$

W; elevation 215 - 300 m a.s.I.) at the Harvard Forest Long Term Ecological Research Site in Petersham, Massachusetts, USA (Ellison et al. 2010; Fig. 1). As in most New

England forests, the Simes Tract as was cleared for agriculture in the early and mid-1800s. Many of the trees that had regenerated following agricultural abandonment in the mid- to late-1800s were blown down in the 1938 Great Hurricane, and analysis of tree-cores from the tract show that the trees in our experimental plots average $55-80$ years old (Bettmann-Kerson 2007; A. M. Ellison, D. A. Orwig \& A. A. Barker Plotkin unpublished data), The soils are predominantly coarse-loamy, mixed, active, mesic Typic Dystrudepts in the Charlton Series that are derived from glacial till (USDA n.d.). Across the eight HF-HeRE study plots, the soil pH ranges from $3.0-3.4$ in the organic layer and from $3.5-4.0$ in the mineral layer, and the soil C:N ratios range from $26-33$. Much of the central portion of the tract is poorly drained or swampy; elevated areas are better drained. Tsuga canadensis and Acer rubrum L. (red maple) dominate the poorly 
172 drained soils, whereas T. canadensis, along with Quercus rubra L. and Q. alba L. (red

173 and white oaks), and Pinus strobus L. (white pine) predominate on hills and slopes.

174 Betula lenta L. (black birch), Acer saccharum Marsh. (sugar maple), and other

175 hardwoods grow at low frequency and density throughout the tract (Ellison et al. 2010).

176

177 Experimental design and treatments

178 The complete design of HF-HeRE is described by Ellison et al. (2010); only salient 179 details are repeated here. The eight $90 \times 90 \mathrm{~m}(0.81 \mathrm{ha})$ plots comprising this 180 experiment are grouped in two blocks (Fig. 1), each consisting of three plots initially 181 dominated by T. canadensis and one plot of mixed hardwoods (Table 1). The "valley" 182 block (plots 1-3 and 8) is in undulating terrain bordered on its northern edge by a 183 Sphagnum-dominated wetland (permission to work in this wetland and in the adjacent 184 bordering vegetation ["buffer zone"] was provided by the Petersham, Massachusetts, 185 Conservation Commission). The "ridge" block (plots 4-7) is on a forested ridge. Plots 186 were identified in 2003 and sampled for two growing seasons (spring/summer in each of 1872003 and 2004) prior to applying canopy manipulation treatments - girdling, or 188 189 harvesting of standing T. canadensis along with cutting of merchantable hardwoods and P. strobus - to one plot in each block.

In the girdled treatment plots, the bark and cambium of all individual $T$.

191

192

193

194 canadensis trees, saplings, and seedlings were cut through using chain saws or hand knives over a 2-day period in May 2005. Girdled trees died over a 2-year period but were left standing in place to simulate the physical decline and mortality of hemlock resulting from infestation by the hemlock woolly adelgid (Ellison et al. 2010). No other 
195

196

197

198

199

200

201

202

203

204

205

206

207

208

209

210

211

212

213

214

215

216

species were girdled and there was no site disturbance other than walking between trees.

In the logged treatment plots, all $T$. canadensis trees $>20 \mathrm{~cm}$ diameter at breast height (DBH, measured $1.3 \mathrm{~m}$ above ground) and $50 \%$ of the commercially valuable $Q$. rubra and $P$. strobus were felled using a chainsaw and removed using a skidder between February and April 2005, when the ground was frozen. Because this logging operation mimicked the effects of an intensive commercial hemlock salvage operation, trees of small size, poor quality, or little economic value, such as $A$. rubrum and B. lenta were also removed to facilitate log removal or to improve future stand quality while retaining some good-quality $Q$. rubra and $P$. strobus. We recognize that the removal of tree species other than $T$. canadensis can have some impacts on changes forest dynamics in the otherwise hemlock-dominated stands. However, in the logged plots, $T$. canadensis accounted initially for $>50 \%$ of the basal area, but made up $>80 \%$ of both the number of felled trees and their basal area (Ellison et al. 2010). Thus, the effects of hemlock loss were likely to dominate that response of the forest to this canopy manipulation.

Two control plots in each block were not manipulated. In each block, one of each of these control plots was dominated by hemlock, the other by mid-successional hardwoods of the same general age of the remaining forest (55-80 years). The latter control plots represents the most likely future forest conditions after hemlock has disappeared from the landscape (Orwig \& Foster 1998; Ellison et al. 2010). 
Vegetation structure

219

220

221

222

223

224

225

226

We measured species richness and cover of understory herbs, and density and cover of tree seedlings and saplings to determine how these attributes of vegetation structure varied among the two canopy manipulation treatments and the two different controls (Prediction 1). In 2003 (prior to canopy manipulations), we established two transects running through the central $30 \mathrm{~m} \times 30 \mathrm{~m}$ of each plot to quantify understory richness, cover, and density. Five 1- $\mathrm{m}^{2}$ subplots were spaced evenly along each transect and have been sampled annually since 2003 . In each subplot, tree seedlings ( $<1.3 \mathrm{~m}$ tall) are counted and percent cover of tree seedlings, herbs, shrubs, ferns and grasses was estimated to the nearest one percent. Grasses and sedges were identified only to genus as most lacked flowerw or fruits necessary for accurate species-level identification. A species list has been compiled annually for the central $30 \times 30-\mathrm{m}$ core area of each plot. Nomenclature follows Haines (2011). The number of sapling-sized trees $(>1.3 \mathrm{~m}$ tall but $<5 \mathrm{~cm}$ DBH) was tallied by species in the $30 \times 30$-m core area of each plot in 2005, 2007 and 2009.

In 2003-2004, all trees $\geq 5 \mathrm{~cm}$ DBH in each plot were tagged with aluminum tags, identified, measured (DBH) and mapped ( $x, y, z$ coordinates relative to a plot corner) using a compass, auto-level, and stadia rods. Initial basal area was higher in the hemlock plots $\left(45.6-53 \mathrm{~m}^{2} \cdot \mathrm{ha}^{-1}\right)$ than in the hardwood control plots $\left(29.7-35.6 \mathrm{~m}^{2}\right.$. $\mathrm{ha}^{-1}$ ) and basal area was slightly higher in the ridge block than the valley block (species composition data reported in Table 1 of Ellison et al. 2010). Initial stem density ranged from 678 stems ha $^{-1}$ in the ridge hemlock control plot to 1354 stems ha ${ }^{-1}$ in the valley 
240 girdled plot. Tsuga canadensis comprised $50-69 \%$ of initial basal area and $55-70 \%$

241 of initial stem density in the six plots initially dominated by this species (hemlock control,

242 logged, and girdled plots). In the hardwood control plots, T. canadensis comprised

$243<10 \%$ of the initial basal area and $10-11 \%$ of the initial stem density. Other species that

244 comprised $>10 \%$ initial basal area in any plot included $A$. rubrum, and $A$. saccharum

245 (hardwood valley plot only), B. lenta, Q. rubra, and P. strobus. Decline and death of

246 trees in the girdled plots was tracked following treatments; most T. canadensis had died

247 within 24 months (Ellison et al. 2010). In 2009, each tree was assessed for survival and

248 diameter growth (for living stems).

249

250 Standing and downed dead wood

251 Prediction 2 addresses changes in volume of coarse woody debris (CWD) - standing

252 dead trees (snags), stumps, and volume of fallen boles and branches $>7.5 \mathrm{~cm}$ in

253 diameter - as a function of canopy manipulation treatment. These variables have been

254 surveyed biennially since 2005 (post-treatment only). In summer 2005, just after the

255 girdling and logging were completed, eight transects were established in each plot

256 beginning from each cardinal and ordinal plot corner/edge and extending 35-50 m

257 towards the plot center. To measure standing dead wood, snags and stumps were

258 sampled along a 4-m wide strip plot that straddles the line transect. Species (or species

259 group) were recorded for each individual stump or snag; its lower diameter was

260 measured, and its top diameter and height were either measured directly or estimated if

261 the snag height exceeded the length of a stadia rod. From these measurements snag

262 volume was calculated as the frustum of a cone (Harmon \& Sexton 1996). Volume of 
263 downed wood was estimated using the line-intercept method (Van Wagner 1968). The

264 diameter, decay class (Rice et al. 2004), and species (or species group) of each piece

265 that intersected the line was recorded.

266

267

Ecosystem function

268 Prediction 3 was that primary productivity, soil carbon flux, and soil nutrient cycling and 269 availability should decline slowly in the girdled plots and rapidly in the logged plots. We 270 use litterfall as an index of annual aboveground productivity (e.g., Zheng et al. 2004).

271 Five litterfall baskets (collection area $0.11 \mathrm{~m}^{2}$ ) were placed at random coordinates 272 throughout each $90 \times 90-\mathrm{m}$ plot. Baskets were placed in the field at the beginning of 273 September 2005 (after canopy manipulations had been applied). Samples were collected quarterly: in early April, mid-June, mid-September, and early December every year. Leaf litter was sorted to major species groups (Tsuga, Pinus, Quercus, Betula, Acer, other deciduous trees), whereas twigs, bark, and reproductive parts were pooled into one category. After sorting, samples were oven-dried at $70{ }^{\circ} \mathrm{C}$ for 48 hours prior to weighing. Annual litterfall is reported as the total of the June, September and December collections, plus the subsequent year's April collection. vented, flow-through, non-steady-state system (Livingston \& Hutchinson 1995) at six 282 randomly chosen locations in the $30 \times 30-\mathrm{m}$ core area of each of the six hemlock 283 (control, girdled, logged) plots (2003 - 2009) and at two randomly chosen locations in 284 the two hardwood control plots $(2006-2007)$. At each location, soil respiration collars, 285 each $25 \mathrm{~cm}$ in diameter $\left(0.05 \mathrm{~m}^{2}\right.$ surface area) made from thin-walled polyvinylchloride 
286 (PVC) tubing cut into $10 \mathrm{~cm}$ lengths, were inserted $\approx 5 \mathrm{~cm}$ into the ground. Soil

287 respiration was measured manually every 2 weeks during the growing season between

288 09:00 and 15:00 hours using a Li-Cor 6252 portable Infrared Gas Analyzer (IRGA)

289 (Li-Cor Inc., Lincoln, Nebraska, USA) mounted on a backpack frame. The IRGA was

290 connected to a vented white acrylonitrile-butadiene-styrene (ABS) chamber top (10 cm

291 in height) that was then placed over the soil respiration collar. A pump circulated the air

292 at $0.5 \mathrm{~L} \cdot \mathrm{min}^{-1}$ from the chamber top through the IRGA and back to the chamber top.

293 The chamber top was left on the collar for $5 \mathrm{~min}$, and the change in $\mathrm{CO}_{2}$ concentration

294 within the chamber was recorded using a Hewlett-Packard HP 200LX palmtop computer

295 (Hewlett-Packard, Palo Alto, California, USA). The calibration of the IRGA was checked

296 each day that measurements were made using both zero $\mathrm{mL} \cdot \mathrm{L}^{-1} \mathrm{CO}_{2}$ and $594 \mathrm{~mL} \cdot \mathrm{L}^{-1}$

$297 \mathrm{CO}_{2}$ certified standards. A linear regression of concentration of $\mathrm{CO}_{2}$ versus time was

298 used to determine the soil respiration rate, which was then corrected for local

299 atmospheric pressure and chamber air temperature. The response variable used in

300 subsequent analyses of treatment effects was soil respiration for the entire sampling

301 period (Day of Year [DOY] 191- 273); this value was estimated by linearly interpolating

302 soil respiration measurements between sampling days for each collar and then

303 summing (integrating) all values over the 82-day sampling period.

304 Total soil respiration is the sum of two belowground components: heterotrophic

305 (microbial and microfaunal respiration) and autotrophic (root respiration). Measurements

306 of soil respiration in the control plots represent the sum of these belowground

307 processes. Thus, to a first approximation, differences in soil respiration between control

308 and either logged or girdled treatments reflect the contribution of eastern hemlock to 
309

310

311

312

313

314

315

316

317

autotrophic respiration. Decreased soil respiration due to treatment effects were calculated by taking the pre-treatment soil respiration over the sampling season and subtracting from it the post-treatment seasonal soil respiration. These decreases represent a conservative estimate of autotrophic soil respiration in treated plots. Potential limitations to this method include the loss of root biomass which could reduce heterotrophic respiration of soil organic matter via lack of priming and the newly severed roots may temporarily increase carbon available for heterotrophic respiration.

Because the majority of live tree roots in each plot were killed following logging or girdling of hemlock and because the percent cover of other vegetation in these treatments at the beginning of this study was very low $(<2 \%)$, seasonal sums of soil respiration in these canopy manipulation treatments can be used as estimates of heterotrophic soil respiration (Hanson et al. 2000; Levy-Varon et al. 2012).

Nitrogen (N) mineralization measurements were begun in August 2003, two growing seasons prior to canopy manipulations, using a modified core method (Hart et al. 1994; Robertson et al. 1999). In the central $30 \times 30-m$ area of each canopy manipulation plot, closed-topped cores were installed within four, $5 \times 5$-m randomly located subplots each year at 7-week intervals during the growing season (May October), and for a 23-week overwinter (October/November - April) incubation. At the beginning of each sampling period, soil was extracted with sharpened PVC cores (25-cm long) and immediately separated into mineral and organic layers. A second core was incubated in the field for 42 - 50 days and then removed and separated by horizon. The bottom $2 \mathrm{~cm}$ of each core was removed to prevent root invasion from below in incubated cores, and to standardize sample volume among the cores. 
Soil samples were returned to the laboratory on ice and processed the next day. Organic and mineral soils were passed through a 5.0-mm mesh screen, weighed for total mass, and subsampled for gravimetric moisture and inorganic N. To determine soil $\mathrm{NH}_{4}-\mathrm{N}$ and $\mathrm{NO}_{3}-\mathrm{N}$ concentration, $\sim 10 \mathrm{~g}$ of organic and mineral soil were placed into 100 $\mathrm{ml}$ of $1 \mathrm{M} \mathrm{KCl}$ for $48 \mathrm{hr}$ (Aber et al. 1993). Soil extracts were filtered through a coarse pore filter $(0.45-0.6 \mu \mathrm{m})$ and inorganic $\mathrm{N}$ concentrations were determined colorimetrically with a Lachat 8500 flow-injection autoanalyzer (Lachat Instruments, Inc., Milwaukee, Wisconsin, USA), using the salicylate (Lachat Instruments, Inc., 1990a) and cadmium reduction methods (Lachat Instruments, Inc., 1990b) for $\mathrm{NH}_{4}-\mathrm{N}$ and $\mathrm{NO}_{3}-\mathrm{N}$, respectively. Net $\mathrm{N}$ mineralization was calculated as the difference in concentration of inorganic $\mathrm{N}\left(\mathrm{NH}_{4}-\mathrm{N}+\mathrm{NO}_{3}-\mathrm{N}\right)$ in incubated cores minus that in initial samples.

An additional assessment of forest floor $\mathrm{N}$ availability and mobility was determined at each soil subplot using mixed-bed cation + anion resin bags (Binkley \& Matson 1983). Approximately 10 grams of resin was placed in nylon mesh bags and pretreated with $2 \mathrm{M} \mathrm{KCl}$ before deployment for 6-month intervals (growing season and overwinter). Resins were deployed at the forest floor - mineral soil interface within $5 \mathrm{~cm}$ of where the $\mathrm{N}$ mineralization incubations were located. Resins were returned to the laboratory on ice, dried at $105{ }^{\circ} \mathrm{C}$ for $24 \mathrm{~h}$, and extracted in $2 \mathrm{M} \mathrm{KCl}$. Inorganic $\mathrm{N}$ was determined by the methods described above for soil $\mathrm{N}$ extracts.

\section{Statistical analysis and data availability}

322 The experimental design is a one-way blocked analysis of covariance (ANCOVA)

323 (Ellison et al. 2010; Gotelli \& Ellison 2012), and analyses reported here were executed 
324 using the Ime function in the nlme package in R version 2.9.2 (R Development Core

325 Team 2009; Pinheiro et al. 2012). In this design, the four canopy manipulations

326 (hemlock control, hemlock girdled, logged, hardwood control) were treated as "fixed"

327 factors, the two blocks were treated as "random" factors, and time entered the model as

328 a covariate. Measures of vegetation structure and ecosystem function parameters were

329 log-transformed as needed to normalize data and equalize variances; data are plotted

330 back-transformed (Gotelli \& Ellison 2012). Comparisons among treatments were done

331 using a priori contrasts. Although two blocks is the minimum required to allow for

332 estimates of variance within treatments, this small number of blocks provided relatively

333 low statistical power to detect true differences among treatments (i.e., the probability of

334 a Type II error - falsely accepting the null hypothesis - is high). Further, the absence of

335 replication of treatments within blocks precluded estimation of a block $\times$ treatment

336 interaction. Such trade-offs are inevitable in hectare-scale, decades-long experiments,

337 however.

$338 \quad$ All data presented in this paper are publicly available through the Harvard Forest

339 Data Archive (http://harvardforest.fas.harvard.edu/data-archive), in a suite of datasets:

340 HF106 (understory vegetation), HF126 (overstory vegetation), HF161 (litterfall), HF125

341 (coarse woody debris), HF119 and HF130 (soil respiration), and HF179 (nitrogen pools

342 and dynamics).

343 


\section{Results}

\section{Changes in vegetation structure}

\section{Overstory trees}

347 Following treatments, the girdled and logged treatments lost $67-72 \%$ of overstory 348 basal area and $61-71 \%$ of overstory stem density (Table 1). Only T. canadensis was

349 affected in the girdled treatment, but girdled individuals ranged from seedlings to 350 canopy trees and they died within 2 years (data in Fig. 4 of Ellison et al. 2010). In

351 contrast, basal area was immediately lost in the logged treatment and included 352 large-diameter T. canadensis, some large Q. rubra and $P$. strobus, and many smaller $A$. 353 rubrum and B. lenta (Table 1). By 2009, four years after manipulations, growth of trees 354 in the hemlock and hardwood control treatments resulted in per-plot gains in basal area 355 of $4 \%-6 \%$; concomitant background mortality led to a per-plot loss of $6-12 \%$ of 356 stems. 
Understory vegetation

359 Understory species richness remained relatively constant in both hemlock control and

360 hardwood treatments over the course of the study, with hardwood treatment plots

361 having the highest herb and shrub richness (Fig. 2a, Table 2). Girdled treatment plots

362 had $<10$ understory species prior to treatment. Species richness in this treatment

363 increased gradually, resulting in a doubling by 2009 (Fig. 2a, Table 2). Two nonnative

364 species were first identified in the girdled treatment at low abundance by 2007: Berberis

365 thunbergii DC. (Japanese barberry) in the valley girdled plot and Celastrus orbiculatus

366 Thunb. (oriental bittersweet) in the ridge girdled plot. The plots in the logged treatment

367 similarly began with low species richness. In contrast to the girdled treatment,

368 understory species richness increased following logging, but then remained

369 approximately constant for the remainder of the study period (Fig. 2a, Table 2). No

370 nonnative species had recruited into the logged treatment plots by 2009. 

and from 16 to $32 \%$ in the hardwood control treatment throughout the sampling period (Fig. 2b, Table 2). Percent cover of understory vegetation increased slowly in the girdled treatment and exceeded cover in the hemlock control treatment by 2009. Understory cover increased more rapidly in the logged treatment, especially after 2007 (Fig. 2b), significantly exceeding cover in both the hemlock control and the girdled treatments, and equaling levels seen in the hardwood control by 2009 (Fig. 2b). The main species driving the increase in understory cover were early successional opportunists and species with long-lived seed banks, including Aralia hispida Vent. (bristly sarsaparilla), blackberries), and to a lesser extent, Lysimachia quadrifolia L. (whorled loosestrife) and Dennstaedtia punctilobula Michx. (T. Moore) (hay-scented fern).

Tree regeneration

Tree seedling density was low in the hemlock control and logged treatments both before and after canopy manipulations (Fig. 2c); it was nearly 10-fold higher in the hardwood control and this significant difference (Table 2) persisted from 2003 - 2009. Tree seedlings, especially of $B$. lenta and $A$. rubrum increased significantly - to $3.5 \times 10^{5}$. $h^{-1}-$ in the girdled treatment through time. Cover of tree seedlings was consistently 390 lowest in hemlock control ( $<1 \%$ cover) and hardwood control ( $\approx 5 \%$ cover) treatments, 391 but increased slowly and significantly in both girdled (to $>40 \%$ cover) and logged (to $39215 \%$ cover) treatments (Fig. 2d; Table 2). 
Prior to the manipulations, there were few saplings in any of the plots, and

394 despite some growth, we observed neither significant changes in sapling density through time nor differences in sapling density among treatments (Fig. 2e). The few 396 saplings in the hemlock control treatment were eastern hemlock. Likewise, sapling 397 density was low in the hardwood control treatment throughout the study period; $A$. 398 rubrum and $A$. saccharum were the most common sapling species in the valley 399 hardwood plot, whereas $A$. rubrum and $P$. strobus were more common in the ridge 400 hardwood plot. The girdling treatment removed all T. canadensis saplings, and even by 4012009 , most tree regeneration in the girdled plots was still in the seedling ( $<1.3-\mathrm{m}$ tall) 402 size class and no stems had grown into the sapling size class until 2009. Most saplings 403 in the logged treatment were killed during logging, but stump sprouts of $A$. rubrum were 404 abundant by 2007 and a few $B$. lenta had grown from seedlings into saplings on the 405 ridge. By 2009 , dense stands (3000 - 6000 saplings ha ${ }^{-1}$ ) of $B$. lenta saplings covered 406 the logged treatment plots.

\section{Standing and downed dead wood}

Volume of stumps and snags was very low in the hemlock and hardwood controls and in

410 the logged treatment plots (Fig. 2f). Volume of stumps and snags in the girdled

411 treatment was similar to both controls in 2003 but then rose significantly (Table 2), by

412 two orders of magnitude, as the girdled trees died (Fig. 2f). Volume of downed CWD in

413 the logged treatment was $2-3 \times$ greater than in any other treatment (Fig. 2 g, Table 2).

414 This trend persisted through the five post-treatment years, although CWD volume 415 declined from $2005-2009$ as the wood decayed. 


\section{Ecosystem function}

\section{Litterfall}

419 Litterfall in the hemlock and hardwood controls were not significantly different from one another and remained relatively constant $\left(3-4 \times 10^{3} \mathrm{~kg} \mathrm{ha}^{-1}\right)$ over the course of the study (Fig. 3a, Table 3). Total litterfall and hemlock litterfall amounts were significantly affected by hemlock removal (Table 3), and the patterns of change in canopy structure were reflected immediately in litterfall (Fig. 3a, 3b). A strong pulse of litter occurred in the girdled treatment in Spring - Summer 2006, one year after T. canadensis were girdled (Fig. 3a). Hemlock litter comprised $>80 \%$ of the total litterfall collected in the girdled treatment during April - September 2006 (Fig. 3b). Subsequently, total litterfall in this treatment increased to about the same amount as in the hemlock and hardwood controls by 2009, but was composed mainly of Betula, Quercus and Pinus litter (data not shown). Litterfall in the logged plots was significantly reduced by logging, and slowly increased during the four years after logging to nearly $50 \%$ of that observed in the 431 controls (Fig. 3a).

Soil respiration

Average seasonal soil respiration dynamics showed some changes as a function of hemlock canopy removal (Fig. 3c), but within-plot variation exceeded among-treatment variation in soil respiration (Fig. 3c; Table 3). By differencing, hemlock roots account for approximately $35 \%$ of the total soil respiration in intact hemlock stands. 
Nitrogen dynamics

440

441

442

443

444

445

446

447

448

449

450

451

452

453

454

455

456

457

458

459

460

461

Hemlock removal led to transient increases in ammonium $\left(\mathrm{NH}_{4}{ }^{+}\right)$and nitrate $\left(\mathrm{NO}_{3}{ }^{-}\right)$

availability in soils (peaks in Fig. 3d, 3e). As with measures of soil respiration, within-treatment heterogeneity exceeded among-treatment variation in $\mathrm{NO}_{3}$ availability, and neither treatment significantly altered soil $\mathrm{NO}_{3}$ availability (Table 3). Nitrate mobility remained low following cutting or girdling, except for a 2-year pulse beginning in 2008 in the girdled plot on the ridge and beginning in 2007 in the logged plot on the ridge (Fig. 3e).

Across all treatments, net nitrogen mineralization declined significantly through time (Table 3), but within-treatment variation exceeded among-treatment variation throughout the study (Fig 3f). We observed a small $(\approx 5 \%)$, sustained increase in net nitrogen mineralization in the girdled treatment from 2007 to 2009, and a similarly small, albeit transient, increase in net nitrogen mineralization immediately following logging (Fig. 3f).

\section{Discussion}

Losses of individual species can have cascading effects on system-wide biological diversity and ecosystem function, but whether specific species have different effects on ecosystem structure function remains an open question that has been addressed much more in theory than in practice (Bunker et al. 2005, Suding et al. 2008, Wardle et al. 2011). It is important to distinguish between effects of loss of dominant (in terms of basal area or biomass) or abundant species and effects of loss of foundation species. For example, American beech is declining rapidly due to beech-bark disease (Houston 
462 1975; Lovett et al. 2006), but because beech resprouts readily, one consequence of

463 beech-bark disease has been to change the size structure of these forests. Large beech

464 trees are now uncommon, but the number of saplings (sprouts) and even the amount of

465 beech's basal area in a stand may be much greater than before the occurrence and

466 spread of the disease (Houston 1975). Similarly, American elm, once an at least

467 co-dominant in many eastern North American forests, continued to recruit from small

468 trees, which can reproduce before they are killed by Dutch elm disease (Barnes 1976).

469 Understory composition changes rarely in beech stands infested by beech-bark disease

470 (Twery and Patterson 1984),.and several authors have failed to find expected changes

471 in invertebrate or mammal abundance associated with widespread decline in beech

472 nuts formerly produced by large trees (Faison and Houston 2004, Garneau et al. 2012).

473 Effects of beech decline on energy and nutrient cycling varies with co-occurring

474 hardwoods, rates of resprouting, and intensity of infestation (Lovett et al. 2006).

475 In contrast, eastern hemlock has distinctive assemblages of understory plants

476 and animals (Snyder et al. 2002; Tingley et al. 2002; Ellison et al. 2005b; Dilling et al.

477 2007; Mathewson 2009; Rohr, Mahan \& Kim 2009; Mallis \& Rieske, 2011; Sackett et al.

478 2011), and affects carbon cycling and hydrological processes differently from both

479 co-occurring hardwoods and co-occurring conifers (Ford \& Vose 2007, Hadley et al.

480 2008, Brantley, Ford \& Vose in press). Hemlock, unlike hardwoods, does not resprout,

481 and the hemlock woolly adelgid feeds on all ages and size-classes of hemlock. Thus,

482 there is neither opportunity for rapid regeneration through resprouting nor is there an

483 opportunity for hemlock seedlings to reach maturity and fruit before they are killed by

484 the adelgid. Eastern hemlock, therefore, is a better candidate for a foundation tree 
485

486

487

488

489

490

491

492

493

494

495

496

497

498

499

500

501

502

503

504

505

506

507

species than many other forest dominants, and its decline and have been hypothesized to lead to both short- and long-term changes in ecological dynamics and ecosystem processes (Ellison et al. 2005a; Lovett et al. 2006).

The Harvard Forest Hemlock Removal Experiment (HF-HeRE) examines this hypothesis by quantifying these changes and testing explicit predictions about how the magnitude and rate of these changes is a function of the mechanism by which a foundation species is lost. In general terms, we predicted that rates of change in biological diversity and ecosystem function would parallel the rate of foundation species loss: slowly when hemlock was girdled (to mimic decline due to infestation by the hemlock woolly adelgid; Yorks et al. 2003) but more rapidly when hemlock was cut and removed (to simulate a commercial logging operation; Brooks 2001). We hypothesize that despite differences in initial rates, changes in vegetation structure and ecosystem function caused by different mechanisms of hemlock loss will converge and come to resemble those seen in the young hardwood stands that represent a plausible scenario of our forests in the future, after hemlock has disappeared from the landscape (Orwig \& Foster 1998). Our results provide strong support for this hypotheses with respect to most measures of vegetation structure, but for fewer measures of ecosystem function.

\section{Changes in vegetation structure}

Decline and loss of $T$. canadensis in the logged and girdled plots at HF-HeRE led to changes in overstory densities and basal area (Table 1) that were similar to those seen in sites long infested by the adelgid (Orwig \& Foster 1998; Orwig, Foster \& Mausel 2002) or that have been salvage logged (Brooks 2001; Kizlinski et al. 2002). Light 
508

509

510

511

512

513

514

515

516

517 518 (Kizlinski et al. 2002).

519

520

521

522

523

524

525

526

527

528

529

530

availability near ground-level increased gradually over time following girdling but abruptly after logging, followed by a decline with regrowth in the logged treatment (Lustenhouwer, Nicoll \& Ellison 2012). Average daily soil and air temperatures in logged and girdled plots were $2-4{ }^{\circ} \mathrm{C}$ warmer in summer and cooler in winter relative to the hemlock or hardwood controls, and both diurnal and seasonal variances in temperatures were highest in the logged treatment (Lustenhouwer, Nicoll \& Ellison 2012). Such changes in light and temperature can strongly impact both vegetation community composition (D'Amato, Orwig \& Foster 2009; Farnsworth, Barker Plotkin \& Ellison 2012) and associated ecosystem properties including decomposition (Berg \& McClaugherty 2009), soil respiration (Savage \& Davidson 2001), and nutrient cycling

Removal of $T$. canadensis by girdling or logging resulted in a 2- to 3-fold increase in species richness after either logging or girdling. Consistent with our first prediction, understory cover in the girdled treatment plots increased slowly (Fig. 2a, 2b) because overstory trees died slowly and the majority of snags were still standing and providing partial shade $4-5$ after the canopy manipulation treatment had been applied. We anticipate that understory vegetation in this treatment will continue to increase in cover and species richness. In contrast, understory vegetation cover in the logged treatment plots increased rapidly and matched total cover in the hardwood control plots by 2009 (Fig. 2a, 2b). Shade intolerant species including Rubus spp., Aralia hispida, and Carex spp. initially were absent in all six T. canadensis-dominated plots, but established from both the seed bank and the seed rain in soils scarified by logging (Farnsworth, Barker Plotkin \& Ellison 2012) and grew quickly in these scarified areas. Similar increases in 
531 total richness and cover have been observed following girdling (Yorks et al. 2003; Ford 532 et al. 2012) or salvage logging (Kizlinski et al. 2002; D. Orwig unpublished data) of $T$. 533 canadensis elsewhere. However, the heavy recruitment of birch (Betula spp.) into the 534 sapling layer within 4 years of girdling has not been observed in other girdling studies 535 (Yorks et al. 2003; Ford et al. 2012), perhaps due to lower deer browsing and lack of 536 Rhododendron (Rhododendron maximum) cover that limit rapid recruitment south of our 537 study areas. These results overall highlight the fact that healthy hemlock act as an 538 ecological filter, limiting seedling and understory plant establishment (Rogers 1980; 539 D'Amato, Orwig \& Foster 2009; Orwig et al. 2012). Now that the adelgid has colonized 540 the hemlock control plots, however, they are also poised for change, and will provide 541 important comparisons with responses observed following girdling.

Changes in standing and downed dead wood

544 Changes in coarse woody debris volume (Fig. 2f, 2g) were consistent with our second 545 prediction. By the end of 2009 , most dead trees were still standing in the girdled 546 treatment plots. Once they fall, however, volume of fallen wood will more than double 547 the levels currently found in the logged plots. Ironically, although the hemlock canopy is 548 lost, this large input of CWD onto the soil surface will bring the dead wood structure of 549 this treatment closer to that seen in old-growth T. canadensis stand structure (D'Amato, 550 Orwig \& Foster 2008) than to the volume of standing dead wood or CWD in young

551 hardwood stands. These fallen boles likely will provide safe sites for seedling 552 establishment and cover for amphibians (Mathewson 2009) and, as they decompose, 553 also will slowly release nutrients into the soil. 


\section{Changes in ecosystem functions}

556

557

558

559

560

561

562

563

564

565

566

567

568

569

570

571

572

573

574

575

576

Our third prediction was supported most clearly for changes in litterfall, an index of aboveground primary productivity (Zheng et al. 2004). In the girdled treatment plots, there was a sharp pulse in litterfall followed by a gradual decline (Fig. 3a, 3b; see also Yorks et al. 2003; Nuckolls et al. 2009). This is a transient loss of standing biomass, which then recovered to pretreatment levels as vegetation colonized or regrew in the experimental plots. Total litterfall following girdling recovered within four years to levels observed in both hemlock and hardwood controls as Pinus strobus, Quercus spp. and Betula spp. Very similar patterns and total amounts of litterfall were observed four years after girdling hemlock in southern Appalachian forests (Knoepp et al. 2011). In the logged treatment plots, litterfall immediately decreased following logging then slowly increased. By 2009, however, the amount of litterfall in the logged plots treatment was still lower than in the girdled treatment or either of the two controls (Fig. 3a, 3b). Contrary to our third prediction, variation in soil respiration, nitrogen availability, and nitrogen cycling generally was higher within treatments and years than among treatments or years, and any responses to treatments were modest and transient. Any initial differences among treatments rapidly recovered to pre-treatment levels (Fig. 3c-f).Our approximate autotrophic respiration rate estimates of $36-46 \%$ are similar to the $48 \%$ measured by Gaudinski et al. (2000) at the Harvard Forest using isotopic analysis of respired ${ }^{14} \mathrm{C}$. We measured $43 \%$ autotrophic respiration using the same isotopic analysis methodology as Gaudinski et al. (2000) within the Simes girdled treatment plots (K. Savage \& E. Davidson unpublished data). Similar ranges attributed 
577 to autotrophs have been estimated in other studies (Hansen et al. 2000; Levy-Varon et 578 al. 2012).

579 Despite the dramatic changes caused by girdling and logging in 580 microenvironmental conditions (Lustenhouwer, Nicoll \& Ellison 2012), vegetation 581 structure (Fig. 2; Table 2), and productivity (Fig. 3a, 3b; Table 3) and the transient shifts 582 in carbon dynamics (Fig. 3c; Table 3), our experimental treatments resulted in only 583 modest, short-term changes in nitrogen cycling (Fig.3d-3f; Table 3). Ammonium 584 availability in the girdled treatment plots did not increase until two years after girdling 585 and peaked one year later, a result expected because $T$. canadensis trees did not die or 586 drop their needles immediately. The short-lived duration of nutrient capture on resins is 587 likely related to the rapid regrowth of vegetation in the logging treatment (see also 588 Templer \& McCann 2010). Short-lived increases in ammonium and nitrate availability 589 also have been observed in other logging and girdling studies (Kizlinski et al. 2002; 590 Yorks et al. 2003; Nave et al. 2011), and in adelgid-infested forests (Jenkins, Aber \& 591 Canham 1999; Orwig et al. 2008). Net nitrogen mineralization was not significantly 592 affected by logging or girdling, a result also seen other hemlock studies in girdled 593 (Knoepp et al. 2011) and logged stands (Kizlinksi et al. 2002), and consistent with 594 findings following a substantial physical disturbance (simulated hurricane; Bowden et al. 595 1993). However, we also found no substantive differences in nitrogen mineralization 596 between hemlock and hardwood control plots. The lack of major differences in soil pH or 597 forest floor $\mathrm{C}: \mathrm{N}$ is consistent with these findings, which are also supported by recent 598 meta-analyses (Mueller et al. 2012). 
We caution, however, that it may take much longer than a decade or two for changes in soil dynamics resulting from the loss of hemlock to be manifest (D. J. Lodge personal communication 24 September 2004). One of the dominant drivers of soil dynamics - decomposition of large fallen boles and other coarse woody debris - is very 603 different in hemlock (and other conifer-dominated) stands than in hardwood dominated stands. In the former, brown-rot fungi dominate, and they primarily decompose cellulose. In the latter, white-rot fungi dominate, and they primarily decompose lignin; in 606 general, white-rot fungi are much more efficient (and rapid) decomposers (Hatakka 607 2001; Floudas et al. 2012). We predict that soil nutrient availability will decline significantly only once dead hemlock boles and smaller coarse hemlock woody debris 609 have decomposed and brown-rot fungi disappear, but this may take one or two 610 centuries.

\section{Conclusions}


613 Loss of the foundation tree species, T. canadensis, by either girdling or logging, leads to 614 short- and long-term changes in vegetation structure and ecosystem function. Rapid 615 removal by logging leads to abrupt, rapid changes, whereas girdling (and by inference, 616 the adelgid itself) causes slower but no less important responses of similar magnitude 617 several years later. Vegetation richness, cover, and density increase continuously 618 following hemlock removal and exert strong, potentially stabilizing, biotic control on the 619 fluxes of nutrients. Thus, these ecosystem processes exhibited short-term fluctuations 620 following T. canadensis removal but recovered to near pre-treatment levels within four 621 years, highlighting the resilience - at least in the short-term - of some forest ecosystem 622 processes to disturbances (Bowden et al. 1993; Foster et al. 1997). Results from 623 HF-HeRE, together with results from observations and experiments on other foundation species suggest that their continued losses, together with human responses to ongoing environmental changes, may have profound impacts on the structure and function of 626 forested ecosystems for decades to come. Acknowledgements 627 This research was supported by the U.S. National Science Foundation through its 628 programs in Long Term Ecological Research (DEB 06-20443), Ecosystems Research 629 (DEB 02-36897), and Research Experiences for Undergraduates (DBI 04-52254), and 630 by the U.S. Department of Energy's Office of Science through its Northeast Regional 631 Center of the National Institute for Global Environmental Change under cooperative 632 agreement no. DE-FC02-03ER63613. Mackenzie Bennett, Peter Bettman-Kerson, 633 Charlie Boyd, Naomi Clark, David Franklin, Clarisse Hart, Sultana Jefts, Susan Irizarry, 634 Alanna Kassarjian, Bennet Leon, Natalie Levy, Samantha Marshall, Nicole Mercier, Jan 635 Ng, Amanda Parks, Samantha Petit, Haley Smith, Relena Ribbons, Christy Rollinson, 
636 Ernesto Rodríguez, Tawny Virgilio, Kelly Walton, Matt Waterhouse, and Kristin Williams

637 assisted in the field work. Elizabeth Farnsworth, David Foster, and two anonymous

638 reviewers provided helpful comments on early versions of the manuscript. 
639

640

641

642

643

644

645

646

647

648

649

650

651

652

653

654

655

656

657

658

659

660

661

\section{References}

Aber JD, Melillo JM. 1991. Terrestrial ecosystems. Philadelphia: Saunders College Publishing.

Aber JD, Magill A, Boone R, Melillo JM, Steudler P, Bowden R. 1993. Plant and soil responses to chronic nitrogen additions at the Harvard Forest Massachusetts. Ecological Applications. 3: 156-166.

Albani M, Moorcroft PR, Ellison AM, Orwig DA, Foster DR. 2010. Predicting the impact of hemlock woolly adelgid on carbon dynamics of eastern US forests. Canadian Journal of Forest Research. 40: 119-133.

Anderson P, Brundrett M, Grierson P, Robinson R. 2010. Impact of severe forest dieback caused by phytophthora cinnamomi on macrofungal diversity in the northern Jarrah forest of Western Australia. Forest Ecology and Management. 259: 1033-1040.

Aukema JE, Leung B, Kovacs K, Chivers C, Britton KO, Englin J, Frankel SJ, Haight RG, Holmes TP, Liebhold AM, McCullough DG, Von Holle B. 2011. Economic impacts of non-native insects in the continental United States. PLOS ONE. 6: e24587.

Barbier EB, Hacker SD, Kennedy C, Koch EW, Stier AC, Silliman BR. 2011. The value of estuarine and coastal ecosystem services. Ecological Monographs. 81: 169-193.

Barnes BV. 1976. Succession in deciduous swamp communities of southeastern Michigan formerly dominated by American elm. Canadian Journal of Botany. 54: 19-24. 
662 Berg B, McClaugherty C. 2008. Plant litter decomposition humus formation carbon sequestration, 2nd edition. Berlin: Springer-Verlag.

664

665

666

667

668

Bettmann-Kerson P. 2007. Hemlock removal experiment - dendrochronological record. Harvard Forest Data Archive HF-086. Available at: http://harvardforestfasharvardedu:8080/exist/xquery/dataxq?id=hf086 (accessed 24 October 2012).

Binkley D, Matson P. 1983. Ion exchange resin bag method for assessing forest soil nitrogen availability. Soil Science Society of America Journal. 47: 1050-1052.

Bowden RD, Castro MS, Melillo JM, Steudler PA, Aber JD. 1993. Fluxes of greenhouse gases between soils and the atmosphere in a temperate forest following a simulated hurricane blowdown. Biogeochemistry. 21: 61-71.

Brantley ST, Ford, CR, Vose JM. in press. Future species composition will affect forest water use after loss of eastern hemlock from southern Appalachian forests. Ecological Applications. http://dx.doi.org/10.1890/12-0616.1.

Bridgeland WT, Beier P, Kolb T, Whitham TG. 2010. A Conditional trophic cascade: birds benefit faster growing trees with strong links between predators and plants. Ecology. 91: 73-84.

Brooks RT. 2001. Effects of the removal of overstory hemlock from hemlock-dominated forests on eastern redback salamanders. Forest Ecology and Management. 149: 197-204.

Bunker DE, DeClerck F, Bradford JC, Colwell RK, Perfecto I, Phillips OL, Sankaran M, Naeem S. 2005. Species loss and aboveground carbon storage in a tropical forest. Science. 310: 1029-1031. 
685 Cai YF, Barber P, Dell B, O’Brien P, Williams N, Bowen B, Hardy G. 2010. Soil bacterial 686 functional diversity is associated with the decline of Eucalyptus gomphocephala. Forest Ecology and Management. 260: 1047-1057.

688

689

690

691

692

693

694

695

696

697

698

699

700

701

702

703

704

705

706

Cardinale BJ, Duffy JE, Gonzalez A, Hooper DU, Perrings C, Venail P, Narwani A, Mace GM, Tilman D, Wardle DA, Kinzig AP, Daily GC, Loreau M, Grace JB, Larigauderie A, Srivastava DS, Naeem S. 2012. Biodiversity loss and its impact on humanity. Nature. 486: 59-67.

Cobb RS, Orwig DA, Currie S. 2006 .Decomposition of green foliage in eastern hemlock forests of southern New England impacted by hemlock woolly adelgid populations. Canadian Journal of Forest Research. 36: 1-11.

Cowles RS. 2009. Optimizing dosage and preventing leaching of imidacloprid for management of hemlock woolly adelgid in forests. Forest Ecology and Management. 257: 1026-1033.

D'Amato AW, Orwig DA, Foster DR. 2008. The influence of successional processes and disturbance on the structure of Tsuga canadensis forests. Ecological Applications. 18: 1182-1199.

D'Amato AW, Orwig DA, Foster DR. 2009. Understory vegetation in old-growth and second-growth Tsuga canadensis forests in western Massachusetts Forest Ecology and Management. 257: 1043-1052.

Dilling C, Lambdin P, Grant J, Buck L. 2007 Insect guild structure associated with eastern hemlock in the southern Appalachians. Environmental Entomology. 36: $1408-1414$. 
707 Ellison AM, Bank MS, Clinton BD, Colburn EA, Elliott K, Ford CR, Foster DR, Kloeppel 708 BD, Knoepp JD, Lovett GM, Mohan J, Orwig DA, Rodenhouse NL, Sobczak WV,

709

710

711

712

713

714

715

716

717

718

719

720

721

722

723

724

725

726

727

728 Stinson KA, Stone JK, Swan CM, Thompson J, Von Holle B, Webster JR. 2005a. Loss of foundation species: consequences for the structure and dynamics of forested ecosystems. Frontiers in Ecology and the Environment. 3: 479-486.

Ellison AM, Chen J, Díaz D, Kammerer-Burnham C, Lau M. 2005b. Changes in ant community structure and composition associated with hemlock decline in New England. In: Onken B, Reardon R, eds. Proceedings of the $3^{\text {rd }}$ Symposium on hemlock woolly adelgid in the eastern United States. Morgantown: US Forest Service - Forest Health Technology Enterprise Team, 280-289.

Ellison AM, Barker Plotkin AA, Foster DR, Orwig DA. 2010. Experimentally testing the role of foundation species in forests: the Harvard Forest Hemlock Removal Experiment. Methods in Ecology and Evolution. 1: 168-179.

Eschtruth AK, Cleavitt NL, Battles JJ, Evans RA, Fahey TJ. 2006. Vegetation dynamics in declining eastern hemlock stands: nine years of forests response to hemlock woolly adelgid infestation. Canadian Journal of Forest Research. 36: 1435-1450.

Faison EK, Houston DR. 2004. Black bear foraging in response to beech bark disease in northern Vermont. Northeastern Naturalist. 11: 387-394.

Farnsworth EJ, Barker Plotkin A, Ellison AM. 2012. Seed bank, seed rain, and vegetation dynamics in Tsuga canadensis stands: reorganization of forests after foundation species loss due to logging or simulated attack of Adelges tsugae. Canadian Journal of Forest Research. 42: 2090-2105. 
Fitzpatrick MC, Preisser EL, Porter A, Elkinton J, Ellison AM. 2012. Modeling range dynamics in heterogeneous landscapes: invasion of the hemlock woolly adelgid in eastern North America. Ecological Applications. 22: 472-486.

Floudas D, Binder M, Riley R, Barry K, Blanchette RA, Henrissat B, Martínez AT, Otillar R, Spatafora JW, Yadav JS, Aerts A, Benoit I, Boyd A, Carlson A, Copeland A, Coutinho PM, de Vries RP, Ferreira P, Findley K, Foster B, Gaskell J, Glotzer D, Górecki P, Heitman J, Hesse C, Hori C, Igarashi K, Jurgens JA, Kallen N, Kersten P, Kohler A, Kües U, Kumar TKA, Kuo A, LaButti K, Larrondo LF, Lindquist E, Ling A, Lombard V, Lucas S, Lundell T, Martin R, McLaughlin DJ, Morgenstern I, Morin E, Murat C., Nagy LG, Nolan M, Ohm RA, Patyshakuliyeva A, Rokas A, Ruiz-Dueñas FJ, Sabat G, Salamov A, Samejima M, Schmutz J, Slot JC, St. John F, Stenlid J, Sun H, Sun S, Syed K, Tsang A, Wiebenga A, Young D, Pisabarro A, Eastwood DC, Martin F, Cullen D, Grigoriev IV, Hibbett DS. 2012. The Paleozoic origin of enzymatic lignin decomposition reconstructed from 31 fungal genomes. Science. 336: 1715-1719.

Ford CR, Vose JM. 2007. Tsuga canadenis (L.) Carr. mortality will impact hydrological processes in southern Appalachian forest ecosystems. Ecological Applications. 17: 1156-1167.

Ford CR Elliott KJ Clinton BD Kloeppel BD, Vose JM. 2012. Forest dynamics following eastern hemlock mortality in the southern Appalachians. Oikos: 121: 523-536.

Foster DR, Orwig DA. 2006. Pre-emptive and salvage harvesting of New England Forests: when doing nothing is a viable alternative. Conservation Biology. 20: 959-970. 
752 Foster DR, Aber JD, Melillo JM, Bowden RD, Bazazz FA. 1997. Forest response to 753 disturbance and anthropogenic stress. BioScience. 47: 437- 445.

754 Garneau DE, Lawler, ME, Rumpf AS, Weyburne ES, Cuppernull TM, Boe AG. 2012.

755 Potential effects of beech bark disease on small mammals and invertebrates in $756 \quad$ northeastern US forests. Northeastern Naturalist. 19: 391-410.

757 Gaston KJ. 2010 Valuing common species. Science. 327: 154-155.

758 Gaudinski JB, Trumbore SE, Davidson EA, Zheng S. 2000. Soil carbon cycling in a 759 temperate forest: radiocarbon-based estimates of residence times sequestration $760 \quad$ rates and partitioning fluxes. Biogeochemistry. 51: 33-69.

761 Gotelli NJ, Ellison AM. 2012. A primer of ecological statistics, $2^{\text {nd }}$ edition. Sunderland: $762 \quad$ Sinauer Associates.

763 Hadley JL, Kuzeja PS, Daley MJ, Phillips NG, Mulcahy T, Singh S. 2008. Water use and carbon exchange of red oak- and eastern hemlock-dominated forests in the Northeastern USA: implications for ecosystem-level effects of hemlock woolly adelgid. Tree Physiology. 28: 615-627.

Haines A. 2011. Flora Novae Angliae: a manual for the identification of native and naturalized higher vascular plants of New England. New Haven: Yale University Press.

Hanson PJ, Edwards NT, Garten CT, Andrews JA. 2000. Separating root and soil microbial contributions to soil respiration: a review of methods and observations. Biogeochemistry. 48: 115-146. 
773 Harmon ME, Sexton J. 1996. Guidelines for measurements of woody detritus in forest

774

775

776

777

778

779

780

781

782

783

784

785

786

787

788

789

790

791

792

793

794

795 ecosystems Seattle: US Long-term Ecological Research Network Office, publication number 20.

Hart SC, Stark JM, Davidson EA, Firestone MF. 1994. Nitrogen mineralization immobilization and nitrification. In: Weaver RW, Angle S, Bottomley P, Dezdicek D, Smith S, Tabatabai A, Wollum, eds. Methods of soil analysis, part 2: microbial and biochemical properties. Madison: Soil Science Society of America, Inc., 985-1018.

Hatakka A. 2001. Biodegradation of lignin. In: Hofrichter M, Steinbüchel A, eds. Biopolymers. Biology, Chemistry, Biotechnology, Applications. Volume 1. Lignin, Humic Substances and Coal. Weinheim: Wiley-VCH, 129-180.

Hicke JA, Allen CD, Desai AR, Dietze MC, Hall RJ, Hogg EH, Kashian DM, Moore D, Raffa KF, Sturrock RN, Vogelmann J. 2012. Effects of biotic disturbances on forest carbon cycling in the United States and Canada. Global Change Biology. 18: 7-34.

Hooper DU, Adair EC, Cardinale BJ, Byrnes JEK, Hungate BA, Matulich KL, Gonzalez A, Duffy JE, Gamfeldt L, O'Connor MI. 2012. A global synthesis reveals biodiversity loss as a major driver of ecosystem change. Nature. 486: 105-108.

Houston DR. 1975. Beech bark disease: the aftermath forests are structured for a new outbreak. Journal of Forestry. 73: 660-673.

Huenneke LF. 1985. Understory response to gaps caused by the death of Ulmus americana in central New York. Bulletin of the Torrey Botanical Club. 110: 170-175. 
796 Ingwell LL, Preisser EL. 2011. Using citizen science programs to identify host resistance in pest-invaded forests. Conservation Biology. 25: 182-188.

798

799

800

801

802

803

804

805

806

807

808

809

810

811

812

813

814

815

816

817

818

Jenkins JC, Aber JD, Canham CD. 1999. hemlock woolly adelgid impacts on community structure and $\mathrm{N}$ cycling rates in eastern hemlock forests. Canadian Journal of Forest Research. 29: 630-645.

Kendall KC, Keane RE. 2001. Whitebark pine decline: infection mortality and population trends. In: Tomback DF, Arno SF, Keane, RE, eds. Whitebark pine communities ecology and restoration. Washington DC: Island Press, 221-242.

Kizlinski ML, Orwig DA, Cobb RC, Foster DR. 2002. Direct and Indirect ecosystem consequences of an invasive pest on forests dominated by eastern hemlock. Journal of Biogeography. 29; 1489-1503.

Knoepp JD, Vose JM, Clinton BD, Hunter MD. 2011. Hemlock infestation and mortality: impacts on nutrient pools and cycling in Appalachian forests. Soil Science Society of America Journal. 75: 1935-1945.

Lachat Instruments Inc. 1990a QuickChem method No 10-107-06-1-C Milwaukee: Lachat.

Lachat Instruments Inc. 1990b QuickChem method No 10-107-04-1-A Milwaukee: Lachat.

Levy-Varon JH, Schuster WSF, Griffin KL. 2012. The autotrophic contribution to soil respiration in a northern temperate deciduous forest and its response to stand disturbance. Oecologia. 169: 211-220.

Livingston GP, Hutchinson GL. 1995. Enclosure-based measurement of trace gas exchange: applications and sources of error. In: Matson PA, Harriss RC, eds. 
Biogenic trace gases: measuring emissions from soil and water. Oxford: Blackwell, 14-51.

821

822

823

824

825

826

827

828

829

830

831

832

833

834

835

836

837

838

839

840
Lovett GM, Canham CD, Arthur MA, Weathers KC, Fitzhugh RD. 2006. Forest ecosystem responses to exotic pests and pathogens in eastern North America. Bioscience. 56: 395-405I

Lustenhouwer MN, Nicoll L, Ellison AM. 2012. Microclimatic effects of the loss of a foundation species from New England forests. Ecosphere. 3: 26.

Mallis RE, Rieske LK. 2011. Arboreal spiders in eastern hemlock. Environmental Entomology. 40: 1378-1387.

Mathewson B. 2009. The relative abundance of eastern red-backed salamanders in eastern hemlock-dominated and mixed deciduous forests at Harvard Forest. Northeastern Naturalist. 16: 1-12.

McBride J. 1973. Natural replacement of disease-killed elms. American Midland Naturalist. 90: 300-306.

McClure MS. 1995. Managing hemlock woolly adelgid in ornamental landscapes. Bulletin of the Connecticut Agricultural Experiment Station. 925.

Mueller KE, Hobbie SE, Oleksyn J, Reich PB, Eissenstat DM. 2012. Do evergreen and deciduous trees have different effects on net $\mathrm{N}$ mineralization in soil? Ecology. 93: $1463-1472$.

Myers BR, Walck JL, Blum KE. 2004. Vegetation change in a former chestnut stand on the Cumberland Plateau of Tennessee during an 80-year period (1921-2000). Castanea. 69: 81-91. 
841 Naeem S, Duffy JE, Zavaleta E. 2012. The functions of biological diversity in an age of extinction. Science. 336: 1401-1406.

843

844

845

846

847

848

849

850

851

852

853

854

855

856

857

858

859

860

861

862

Nagelkerken I, Blaber SJM, Bouillon S, Green P, Haywood M, Kirton LG, Meynecke JO, Pawlik J, Penrose HM, Sasekumar A, Somerfield PJ. 2008. The habitat function of mangroves for terrestrial and marine fauna: a review. Aquatic Botany. 89: 155-185.

Nave LE, Gough CM, Maurer KD, Bohrer G, Hardiman BS, Le Moine J, Munoz AB, Nadelhoffer KJ, Sparks JP, Strahm BD, Vogel CS, Curtis PS. 2011. Disturbance and the resilience of coupled carbon and nitrogen cycling in a north temperate forest. Journal of Geophysical Research. 116: G04016.

Nuckolls AE, Wurzburger N, Ford CR, Hendrick RL, Vose JM, Kloeppel BD. 2009. Hemlock declines rapidly with hemlock woolly adelgid infestation: impacts on the carbon cycle of southern Appalachian forests. Ecosystems. 12: 179-190.

Onken B, Reardon R. 2011 Implementation and status of biological control of the hemlock woolly adelgid. Morgantown: US Forest Service, Publication FHTET-2011-04.

Orwig DA, Foster DR. 1998. Forest response to the introduced hemlock woolly adelgid in southern New England, USA. Journal of the Torrey Botanical Society. 125: 59-72.

Orwig DA, Foster DR, Mausel DL. 2002. Landscape patterns of hemlock decline in New England due to the introduced hemlock woolly adelgid. Journal of Biogeography. 29: $1475-1487$. 
863 Orwig DA, Cobb RC, D'Amato AW, Kizlinski ML, Foster DR. 2008. Multi-year ecosystem

864

865

866

867

868

869

870

871

872

873

874

875

876

877

878

879

880

881

882

883 response to hemlock woolly adelgid infestation in southern New England forests. Canadian Journal of Forest Research. 38: 834-843.

Orwig DA, Thompson J, Povak NA, Manner M, Niebyl D, Foster DR. 2012. A foundation tree at the precipice: eastern hemlock health following the arrival of Adelges tsugae in central New England. Ecosphere: 3: 10.

Pinheiro J, Bates D, DebRoy S, Sarkar D, R Development Core Team. 2012. nlme: linear and nonlinear mixed effects models. R package version 31-104. Available at http://cranr-projectorg/web/packages/nIme/ (accessed 1 July 2012)

R Development Core Team. 2009. R: a language and environment for statistical computing. Vienna: R Foundation for Statistical Computing.

Rice AH, Pyle EH, Saleska SR, Hutyra L, Palace M, Keller M, DeCamargo PB, Portilho K, Marques DF, Wofsy SC. 2004. Carbon balance and vegetation dynamics in an old-growth Amazonian forest. Ecological Applications. 14: S55-S71.

Roberston GP, Wedin D, Groffman PM, Blair JM, Holland EA, Nadelhoffer KJ, Harris D. 1999. Soil carbon and nitrogen availability: nitrogen mineralization nitrification and soil respiration potentials. In: Robertson GP, Coleman DC, Bledsoe CS, Sollins P, eds. Standard Soil Methods for Long-term Ecological Research. New York, Oxford University Press, 258-288.

Rogers RS. 1980. Hemlock stands from Wisconsin to Nova Scotia: transitions in understory composition along a floristic gradient. Ecology. 61: 178-193. 
884 Rohr JR, Mahan CG, Kim KC. 2009. Response of arthropod biodiversity to foundation

885

886

887

888

889

890

891

892

893

894

895

896

897

898

899

900

901

902

903

904

905

species declines: the case of the eastern hemlock. Forest Ecology and Management. 258: 1503-1510

Sackett TE, Record S, Bewick S, Baiser B, Sanders NJ, Ellison AM. 2011. Response of macroarthropod assemblages to the loss of hemlock (Tsuga canadenis), a foundation species. Ecosphere. 2: 74.

Savage KE, Davidson EA. 2001. Interannual variation of soil respiration in two New England forests. Global Biogeochemical Cycles. 15: 337-350.

Smith WB, Miles PD, Perry CH, Pugh SA. 2009. Forest resources of the United States, 2007. Washington DC: USDA Forest Service, General Technical Report WO-78

Snyder CD, Young JA, Lemarie DP, Smith DR. 2002. Influence of eastern hemlock forests on aquatic invetebrate asssemblages in headwater streams. Canadian Journal of Fisheries and Aquatic Sciences. 59: 262-275.

Stadler B, Müller T, Orwig D, Cobb R. 2005. Hemlock woolly adelgid in New England forests: canopy impacts transforming ecosystem processes and landscapes. Ecosystems. 8: 233-247.

Stadler B, Müller T, Orwig D. 2006. The ecology of energy and nutrient fluxes in hemlock forests invaded by the hemlock woolly adelgid. Ecology. 87: 1792-1804.

Suding KN, Lavorel S, Chapin FS III, Cornelissen JHC, Díaz S, Garnier E, Goldberg D, Hooper DU, Jackson ST, Navas M-L. 2008. Scaling environmental change through the community-level: a trait-based response-and-effect framework for plants. Global Change Biology. 14: 1125-1140. 
906 Templer PH, McCann TM. 2010. Effects of the hemlock woolly adelgid on nitrogen

$907 \quad$ losses from urban and rural northern forest ecosystems. Ecosystems. 13:

$908 \quad 1215-1226$.

909 Tingley MW, Orwig DA, Motzkin G, Foster DR, Field R. 2002. Avian response to

910 removal of a forest dominant: consequences of hemlock woolly adelgid

911 infestations. Journal of Biogeography. 29: 1505-1516.

912 Twery MJ, Patterson WA III. 1984. Variations in beech bark disease and its effects on

913 species composition and structure of northern hardwood stands in central New

$914 \quad$ England. Canadian Journal of Forest Research. 14: 565-574.

915 United States Department of Agriculture (USDA). nd. Official soil series descriptions.

916 Lincoln: Soil Survey Staff Natural Resources Conservation Service. Available at:

917 http://soilsusdagov/technical/classification/osd/indexhtml (accessed 1 July 2010).

918 Van Wagner CE. 1968. The line intersect method in forest fuel sampling. Forest

$919 \quad$ Science. 14: 20-26.

920 Ward JS, Montgomery ME, Cheah CAS-J, Onken BP, Cowles RS. 2004. Eastern

921 hemlock forests: guidelines to minimize the impacts of hemlock woolly adelgid.

922 Morgantown: USDA Forest Service Northeastern Area State and Private

923 Forestry, publication NA-TP-03-04.

924 Wardle DA, Bardgett RD, Callaway RM, Van der Putten WH. 2011. Terrestrial

925 ecosystem responses to species gains and losses. Science. 332: 1273-1277.

926 Wills RT. 1993. The ecological impact of Phytophthora cinnamomi in the Stirling Range

$927 \quad$ National Park Western Australia. Australian Journal of Ecology. 18: 145-159. 
928 Yorks TE, Leopold DJ, Raynal DJ. 2003. Effects of Tsuga canadensis mortality on soil 929 water chemistry and understory vegetation: possible consequences of an $930 \quad$ invasive insect herbivore. Canadian Journal of Forest Research. 33: 1525-1537. 931 Zheng D, Prince S, Hame T. 2004. Estimating net primary production of boreal forests in 932 Finland and Sweden from field data and remote sensing. Journal of Vegetation $933 \quad$ Science. 15: 161-170 


\section{Table $\mathbf{1}_{\text {(on next page) }}$}

Table 1.

Changes in total average basal area $\left(\mathrm{m}^{2} \mathrm{ha}^{-1}\right)$ and density $\left(\mathrm{ha}^{-1}\right)$ in the treatment plots of the Harvard Forest Hemlock Removal Experiment. 
Table 1. Changes in total average basal area $\left(\mathrm{m}^{2} \mathrm{ha}^{-1}\right)$ and density $\left(\right.$ ha $\left.\mathrm{H}^{-1}\right)$ in the treatment plots of the Harvard Forest Hemlock Removal Experiment.

\begin{tabular}{|c|c|c|c|c|c|}
\hline \multirow[b]{2}{*}{ Canopy/manipulation } & \multirow[b]{2}{*}{ Year } & \multicolumn{2}{|c|}{ Basal area } & \multicolumn{2}{|c|}{ Stem density } \\
\hline & & Valley plots & Ridge plots & Valley plots & Ridge plots \\
\hline \multirow{2}{*}{ Hemiock control } & 2004 & 45.6 & 52.1 & 940 & 678 \\
\hline & 2009 & 47.3 & 54.0 & 842 & 637 \\
\hline \multirow{4}{*}{ Girdled } & 2004 & 50.3 & 53.0 & 1354 & 1011 \\
\hline & 2009 & 15.9 & 17.6 & 395 & 331 \\
\hline & 2004 & 47.9 & 49.5 & 1212 & 1089 \\
\hline & 2009 & 15.4 & 13.8 & 469 & 373 \\
\hline \multirow{2}{*}{ Hardwood control } & 2004 & 29.7 & 35.6 & 1122 & 885 \\
\hline & 2009 & 31.0 & 37.7 & 990 & 807 \\
\hline
\end{tabular}




\section{Table $2_{\text {(on next page) }}$}

\section{Table 2.}

Summary of ANCOVA analyses on vegetation structural characteristics shown in Figure 2. The models fit were all of the form response variable $=\beta 0+\beta 1 \times$ block $+\beta 2 \times$ time $+\beta 3 \times$ treatment + $\beta 4 \times$ timextreatment; if the response variable was $\ln$-transformed prior to analysis, that is noted in the column heading. Values shown in the first four rows are F-statistics, associated degrees of freedom, and $P$-values; parameter estimates (SE) for the four treatments - C (hemlock control); G (girdled), L (logged), and H (hardwood control) - are given in the next three rows. Parameter estimates are not back-transformed (for models fit to ln-transformed data). Parameter estimates that are significantly different from 0 are shown in italics. 
Table 2. Summary of ANCOVA analyses on vegetation structural characteristics shown in Figure 2. The models fit were all of the form response variable $=\beta_{0}+\beta_{1} \times$ block $+\beta_{2} \times$ time $+\beta_{3} \times$ treatment $+\beta_{4} \times$ timextreatment; if the response variable was In-transformed prior to analysis, that is noted in the column heading. Values shown in the first four rows are F-statistics, associated degrees of freedom, and P-values; parameter estimates (SE) for the four treatments - C (hemlock control); G (girdled), L (logged), and $\mathrm{H}$ (hardwood control) - are given in the next three rows. Parameter estimates are not back-transformed (for models fit to In-transformed data). Parameter estimates that are significantly different from 0 are shown in italics.

\begin{tabular}{|c|c|c|c|c|c|c|c|}
\hline (a) & $\begin{array}{c}\text { Understory } \\
\text { richness }\end{array}$ & $\begin{array}{c}\text { Understory } \\
\text { cover }\end{array}$ & $\begin{array}{l}\text { In(Tree } \\
\text { seedling } \\
\text { density) }\end{array}$ & $\begin{array}{c}\text { In(Tree } \\
\text { seedling } \\
\text { cover) }\end{array}$ & $\begin{array}{l}\text { In(Sapling } \\
\text { density + 1) }\end{array}$ & $\begin{array}{c}\text { In(Snag and } \\
\text { stump } \\
\text { volume) } \\
\end{array}$ & CWD volume \\
\hline \multicolumn{8}{|l|}{ Sources of variation } \\
\hline 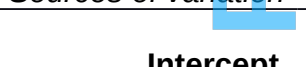 & $F_{1,39}=671.34$ & $F_{1,47}=132.35$ & $F_{1,47}=2967.94$ & $F_{1,47}=0.03$ & $F_{1,15}=148.05$ & $F_{1,15}=1135.32$ & $F_{1,15}=151.22$ \\
\hline Time & $\begin{array}{c}P<0.0001 \\
F_{1,39}=23.65\end{array}$ & $\begin{array}{c}P<0.0001 \\
F_{1,47}=21.82\end{array}$ & $\begin{array}{c}P<0.0001 \\
F_{1,47}=11.80\end{array}$ & $\begin{array}{c}P=0.8615 \\
F_{1,47}=82.57\end{array}$ & $\begin{array}{c}P<0.0001 \\
F_{1,15}=1.27\end{array}$ & $\begin{array}{c}P<0.0001 \\
F_{1,15}=10.85\end{array}$ & $\begin{array}{c}P<0.0001 \\
F_{1,15}=0.00\end{array}$ \\
\hline Treatment & $\begin{array}{c}P<0.0001 \\
F_{3,39}=53.13\end{array}$ & $\begin{array}{c}P<0.0001 \\
F_{3,47}=80.34\end{array}$ & $\begin{array}{c}P=0.0012 \\
F_{3,47}=2.55\end{array}$ & $\begin{array}{c}P<0.0001 \\
F_{3,47}=32.84\end{array}$ & $\begin{array}{c}P=0.2779 \\
F_{3,15}=2.85\end{array}$ & $\begin{array}{c}P=0.0049 \\
F_{3,15}=14.53\end{array}$ & $\begin{array}{c}P=0.9867 \\
F_{3,15}=43.51\end{array}$ \\
\hline Time $\times$ Treatment & $\begin{array}{c}P<0.0001 \\
F_{3,39}=4.29\end{array}$ & $\begin{array}{c}P<0.0001 \\
F_{3,47}=12.58\end{array}$ & $\begin{array}{c}P=0.0668 \\
F_{3,47}=4.16\end{array}$ & $\begin{array}{c}P<0.0001 \\
F_{3,47}=15.14\end{array}$ & $\begin{array}{c}P=0.0728 \\
F_{3,15}=0.49\end{array}$ & $\begin{array}{c}P=0.0001 \\
F_{3,15}=7.39\end{array}$ & $\begin{array}{c}P<0.0001 \\
F_{3,15}=0.90\end{array}$ \\
\hline & $P=0.0104$ & $P<0.0001$ & $P=0.0108$ & $P<0.0001$ & $P=0.6929$ & $P=0.0029$ & $P=0.4634$ \\
\hline Parameter estimates & & & & & & & \\
\hline Intercept $\left(\beta_{0}\right)$ & $8.38(1.57)$ & $0.78(1.62)$ & $10.04(0.34)$ & $-1.98(0.33)$ & $3.42(1.18)$ & $3.22(0.39)$ & $25.42(8.24)$ \\
\hline Time $\left(\boldsymbol{\beta}_{2}\right)$ & $0.06(0.58)$ & $0.15(0.62)$ & $0.18(0.12)$ & $0.22(0.12)$ & $0.02(0.39)$ & $0.08(0.13)$ & $2.89(2.56)$ \\
\hline Treatment $\left(\beta_{3}\right)$ & G: $0.44(2.22)$ & G: 0.49 (2.19) & G: $0.17(0.42)$ & G: $0.15(0.42)$ & G: 0.55 & G: - $-0.29(0.55)$ & G: -2.08 (10.81) \\
\hline
\end{tabular}




\begin{tabular}{ccccccccc} 
& L: $-2.12(2.22)$ & L: $0.32(2.19)$ & L: $0.21(0.42)$ & L: $0.88(0.42)$ & $(1.67)$ & L: $0.05(0.55)$ & L: 64.45(10.81) \\
& H: 17.34 & H: 23.71 & H: $1.07(0.42)$ & H: $3.50(0.42)$ & L: $1.71(1.67)$ & H: $-0.37(0.55)$ & H: $18.51(10.81)$ \\
& $(2.22)$ & $(2.19)$ & & & H: $1.94(1.67)$ & & \\
& G: $2.49(0.82)$ & G: $0.38(0.88)$ & G: $0.36(0.17)$ & G: $0.73(0.17)$ & G: 0.08 & G: $0.66(0.18)$ & G: $-1.82(3.62)$ \\
& L: $2.25(0.82)$ & L: $4.59(0.88)$ & L: $-0.05(0.17)$ & L: $0.7(0.17)$ & $(0.56)$ & L: $-0.10(0.18)$ & L: $-4.28(3.62)$ \\
Time x Treat ( $\left.\beta_{4}\right)$ & H: $0.68(0.82)$ & H: $0.23(0.88)$ & H: $-0.22(0.17)$ & H: $-0.14(0.17)$ & L: $0.61(0.56)$ & H: $0.04(0.18)$ & H: $-5.40(3.62)$ \\
& & & & & H: $0.11(0.56)$ & & \\
\hline
\end{tabular}




\section{Table 3 (on next page)}

\section{Table 3.}

Summary of ANCOVA analyses on ecosystem functional characteristics shown in Figure 3. The models fit were all of the form response variable $=\beta 0+\beta 1 \times$ block $+\beta 2 \times$ time $+\beta 3 \times$ treatment + $\beta 4 \times$ time $\times$ treatment; if the response variable was $\ln$-transformed prior to analysis, that is noted in the column heading. Values shown in the first four rows are F-statistics, associated degrees of freedom, and $P$-values; parameter estimates (SE) for the four treatments - C (hemlock control); G (girdled), L (logged), and H (hardwood control) - are given in the next three rows. Parameter estimates are not back-transformed (for models fit to ln-transformed data). Parameter estimates that are significantly different from 0 are shown in italics. 
Table 3. Summary of ANCOVA analyses on ecosystem functional characteristics shown in Figure 3. The models fit were all of the form response variable $=\beta_{0}+\beta_{1} \times$ block $+\beta_{2} \times$ time $+\beta_{3} \times$ treatment $+\beta_{4} \times$ time $\times$ treatment; if the response variable was In-transformed prior to analysis, that is noted in the column heading. Values shown in the first four rows are F-statistics, associated degrees of freedom, and P-values; parameter estimates (SE) for the four treatments - C (hemlock control); G (girdled), L (logged), and H (hardwood control) - are given in the next three rows. Parameter estimates are not back-transformed (for models fit to In-transformed data). Parameter estimates that are significantly different from 0 are shown in italics.

\begin{tabular}{|c|c|c|c|c|c|c|}
\hline (a) & In(litterfall) & $\begin{array}{c}\text { In(hemlock } \\
\text { litterfall) } \\
\end{array}$ & Soil C flux & $\operatorname{In}\left(\mathrm{NH}_{4}\right)$ & $\mathrm{NO}_{3}$ & $\begin{array}{c}\ln (\mathbf{N} \\
\text { mineralization) }\end{array}$ \\
\hline \multicolumn{7}{|l|}{ Sources of variation } \\
\hline \multirow{2}{*}{ Intercept } & $F_{1,23}=10821.55$ & $F_{1,23}=3.96$ & $F_{1,29}=126.44$ & $F_{1,47}=2347.54$ & $\mathrm{~F}_{1,47}=8.35$ & $F_{1,47}=397.38$ \\
\hline & $P<0.0001$ & $P=0.0587$ & $P<0.0001$ & $P<0.0001$ & $P=0.0058$ & $P<0.0001$ \\
\hline \multirow{3}{*}{ Time } & $F_{1,23}=0.14$ & $F_{1,23}=6.46$ & $F_{1,29}=0.84$ & $F_{1,47}=2.53$ & $\mathrm{~F}_{1,47}<0.01$ & $F_{1,47}=5.66$ \\
\hline & $\mathrm{P}=0.7105$ & $P=0.0182$ & $P=0.3665$ & $P=0.1183$ & $\mathrm{P}=0.9922$ & $\mathrm{P}=0.0214$ \\
\hline & $F_{3,23}=15.95$ & $F_{3,23}=12.45$ & $F_{2,29}=5.69$ & $F_{3,47}=9.00$ & $F_{3,47}=2.44$ & $F_{3,47}=2.26$ \\
\hline Treatment & $\begin{array}{c}\mathrm{P}<0.0001 \\
\mathrm{~F}_{3,23}=3.26\end{array}$ & $\begin{array}{l}P<0.0001 \\
F_{3,23}=5.53\end{array}$ & $\begin{array}{l}\mathrm{P}=0.0083 \\
\mathrm{~F}_{2,29}=2.05\end{array}$ & $\begin{array}{l}P<0.0001 \\
F_{3,47}=2.14\end{array}$ & $\begin{array}{c}\mathrm{P}=0.0757 \\
\mathrm{~F}_{347}=0.91\end{array}$ & $\begin{array}{l}P=0.0933 \\
F_{347}=2.39\end{array}$ \\
\hline Time $\mathrm{x}$ Treatment & $P=0.0399$ & $P=0.0052$ & $P=0.1475$ & $P=0.1075$ & $P=0.4435$ & $\mathrm{P}=0.0806$ \\
\hline \multicolumn{7}{|c|}{ Parameter estimates } \\
\hline Intercept $\left(\beta_{0}\right)$ & $3.86(0.20)$ & $2.87(1.16)$ & $0.29(0.03)$ & $4.67(0.25)$ & $62.80(37.73)$ & $-1.04(0.14)$ \\
\hline Time $\left(\beta_{2}\right)$ & $0.00(0.06)$ & $0.00(0.33)$ & $0.01(0.01)$ & $-0.20(0.10)$ & $-9.77(11.64)$ & $-0.14(0.06)$ \\
\hline \multirow[t]{2}{*}{ Treatment $\left(\beta_{3}\right)$} & G: $0.36(0.27)$ & G: 2.43 (1.50) & G: -0.02 (0.03) & G: $0.46(0.35)$ & G: 15.95 (41.15) & G: $-0.05(0.20)$ \\
\hline & $L:-0.94(0.27)$ & L: -2.53 (1.50) & L: $0.0(0.3)$ & L: $0.84(0.35)$ & L: 59.44 (41.15) & L: $0.23(0.20)$ \\
\hline
\end{tabular}




\begin{tabular}{ccccccc} 
& H: $0.00(0.27)$ & H: $-2.37(1.50)$ & & H: $-0.16(0.35)$ & H: $-17.85(41.15)$ & H: $-0.09(0.20)$ \\
& G: $-0.16(0.09)$ & G: $-1.58(0.47)$ & G: $0.02(0.01)$ & G: $0.33(0.14)$ & G: $25.44(16.46)$ & G: $0.20(0.08)$ \\
Time x Treat $\left(\beta_{4}\right)$ & L: $0.12(0.09)$ & L: $0.10(0.47)$ & L: $0.01(0.01)$ & L: $0.11(0.14)$ & L: $4.49(16.46)$ & L: $0.05(0.08)$ \\
& H: $0.01(0.09)$ & H: $-0.22(0.47)$ & & H: $0.04(0.14)$ & H: $8.92(16.46)$ & H: $0.05(0.08)$ \\
\hline
\end{tabular}

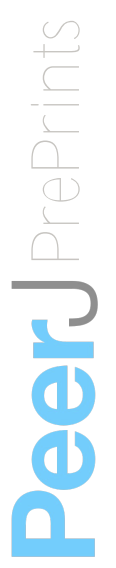




\section{Figure 1}

Location of the Harvard Forest Hemlock Removal Experiment

Location of the Harvard Forest Hemlock Removal Experiment in Massachusetts, USA. The regional map shows the basal area of eastern hemlock at a $1 \mathrm{~km}^{2}$ resolution. The inset shows the location of the experimental blocks and treatments. Plots 1, 2, 3, and 8 make up the valley block; plots $4-7$ make up the ridge block. Each canopy manipulation treatment - hemlock control (He), girdled (G), logged (L), and hardwood control (Hw) - was applied to a $90 \times 90 \mathrm{~m}$ plot within each block.

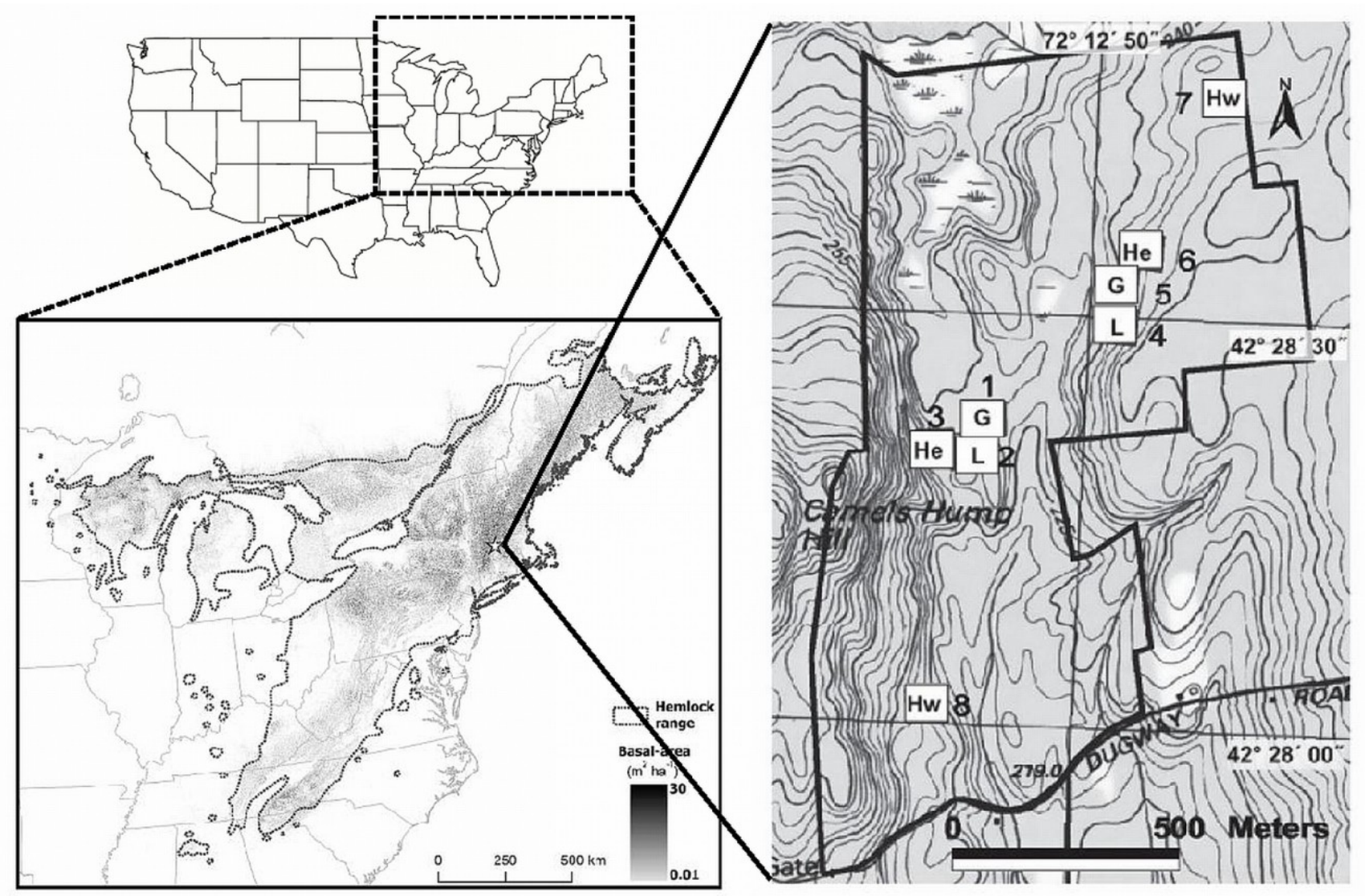




\section{Figure 2}

Temporal changes in vegetation structure following hemlock removal

Temporal trajectories of vegetation structural characteristics in the Harvard Forest Hemlock Removal Experiment. Values shown are plot means and standard deviations (where multiple samples were taken in each plot), back-transformed as necessary. Solid lines and symbols are plots in the valley; dashed lines and open symbols are plots on the ridge. Colors indicate treatments: blue - hemlock controls; yellow - all hemlocks girdled; red - hemlocks logged; lavender - hardwood controls. 

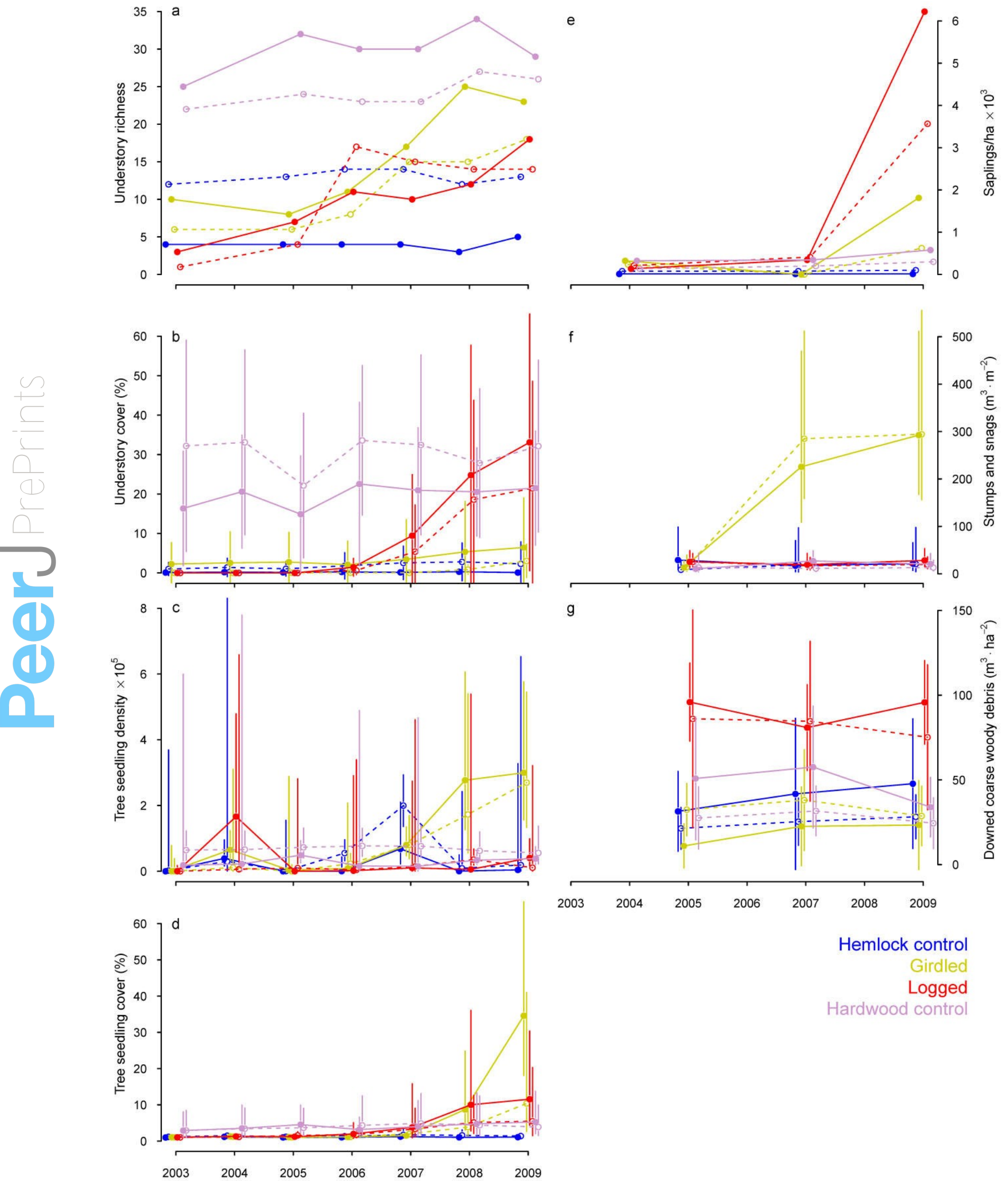

Hemlock control

Girdled

Logged

Hardwood control 


\section{Figure 3}

Temporal changes in ecosystem dynamics following hemlock removal

Temporal trajectories of ecosystem functional characteristics in the Harvard Forest Hemlock Removal Experiment. Values shown are plot means and standard deviations (where multiple samples were taken in each plot), back-transformed as necessary. Solid lines and symbols are plots in the valley; dashed lines and open symbols are plots on the ridge. Colors indicate treatments: blue - hemlock controls; yellow - all hemlocks girdled; red - hemlocks logged; lavender - hardwood controls. 

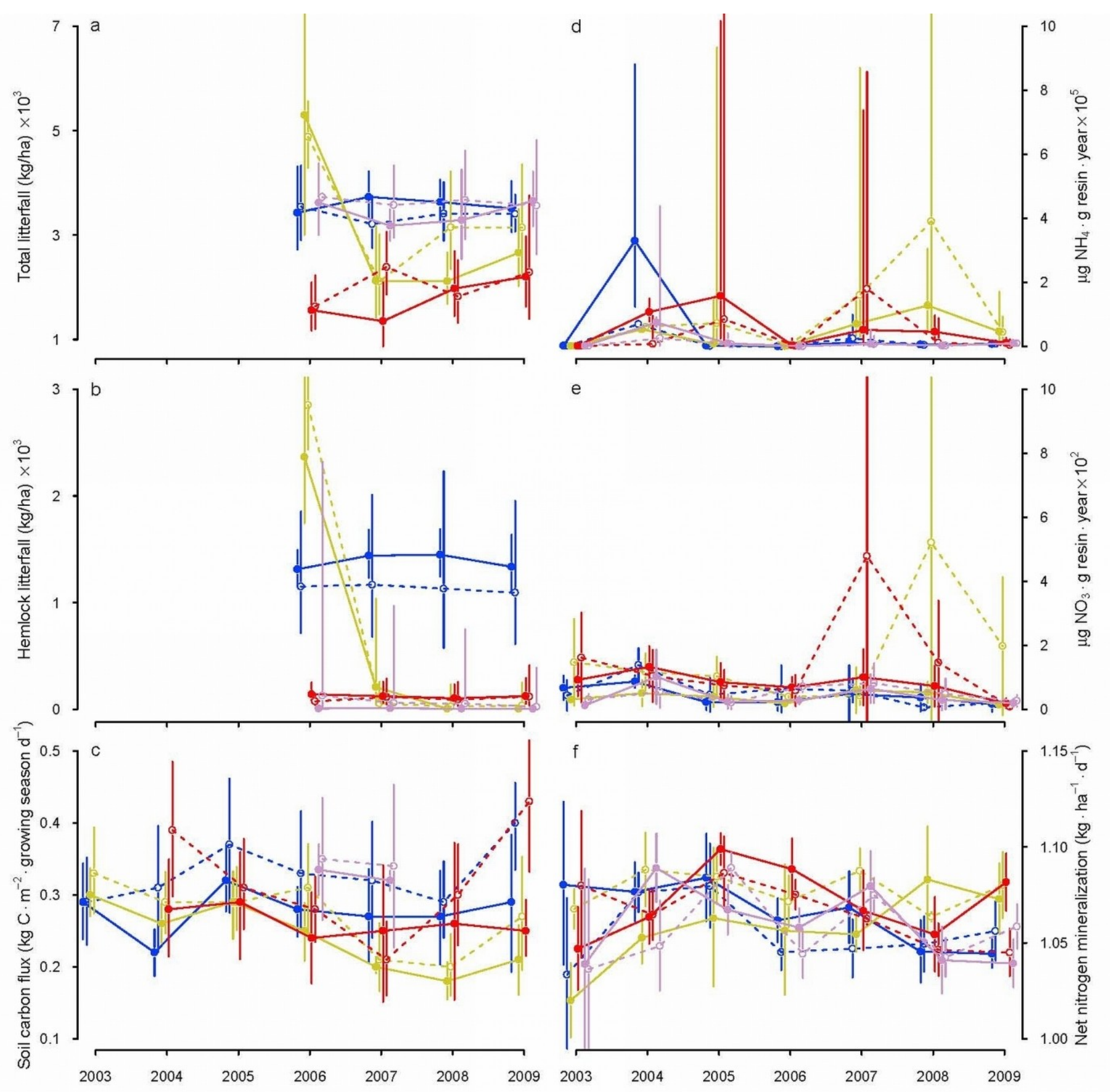